\title{
Mechanistic Approaches for Modifying the Coordination Sphere of Metal-Amyloid- $\beta$ Complexes: Covalent Adduct Formation and Oxidation
}

Jiyeon Han, Hyuck Jin Lee, Kyu Yeon Kim, Junghyun Chae, Mi Hee Lim

Submitted date: 03/05/2019 - Posted date: 06/05/2019

Licence: CC BY-NC-ND 4.0

Citation information: Han, Jiyeon; Lee, Hyuck Jin; Kim, Kyu Yeon; Chae, Junghyun; Lim, Mi Hee (2019):

Mechanistic Approaches for Modifying the Coordination Sphere of Metal-Amyloid- $\beta$ Complexes: Covalent Adduct Formation and Oxidation. ChemRxiv. Preprint.

We report, for the first time, a novel mechanistic tactic to directly modify the coordination sphere of $\mathrm{Cu}(\mathrm{II})-\mathrm{A} \beta$ complexes in a metal binding residue-specific manner, which can prevent $\mathrm{Cu}(\mathrm{II})$ binding to $\mathrm{A} \beta$, modulate the aggregation of $\mathrm{Cu}(\mathrm{II})-\mathrm{A} \beta$, and generate chemically transformed $A \beta$ with less cytotoxicity, to the best of our knowledge.

File list (2)

MS_MHLIM.pdf (1.57 MiB) view on ChemRxiv • download file 


\title{
Mechanistic Approaches for Modifying the Coordination Sphere of Metal-Amyloid- $\beta$ Complexes: Covalent Adduct Formation and Oxidation
}

\author{
Jiyeon Han, ${ }^{\dagger}$ Hyuck Jin Lee, ${ }^{\dagger, \ddagger}$ Kyu Yeon Kim,,$^{\S}$ Junghyun Chae,,$^{\S}$ Mi Hee Lim ${ }^{\dagger, *}$
}

tDepartment of Chemistry, Korea Advanced Institute of Science and Technology (KAIST), Daejeon 34141, Republic of Korea

‡Department of Chemistry Education, Kongju National University, Kongju 32588, Republic of Korea

§Department of Chemistry, Sungshin Women's University, Seoul 02844, Republic of Korea

*To whom correspondence should be addressed: miheelim@kaist.ac.kr 


\section{ABSTRACT}

The impaired homeostasis of redox-active metal ions could contribute to neurodegeneration found in neurodegenerative disorders. In the brain of Alzheimer's disease (AD), redox-active metal ions [particularly, $\mathrm{Cu}(\mathrm{II})$ ] are coordinated to amyloid- $\beta$ (A $\beta$ ) peptides forming metal-A $\beta$ complexes able to generate toxic $A \beta$ oligomers and overproduce reactive oxygen species. To modulate such reactivities of $\mathrm{Cu}(\mathrm{II})-\mathrm{A} \beta$ complexes, various chemical reagents have been developed and used to sequester $\mathrm{Cu}(\mathrm{II})$ from $\mathrm{Cu}(\mathrm{II})-\mathrm{A} \beta$ complexes. No chemical reagent or strategy, however, is currently available to control both $\mathrm{Cu}(\mathrm{II})-\mathrm{A} \beta$ complexation and the oligomerization of the resultant metal-free $A \beta$ upon removal of $C u(I I)$ from $C u(I I)-A \beta$ complexes. Herein, we report, for the first time, a novel mechanistic tactic to directly modify the coordination sphere of $\mathrm{Cu}(\mathrm{II})-\mathrm{A} \beta$ complexes, which can prevent $\mathrm{Cu}(\mathrm{II})$ binding to $\mathrm{A} \beta$, modulate the aggregation of $\mathrm{Cu}(\mathrm{II})-\mathrm{A} \beta$, and generate chemically transformed $A \beta$ with less cytotoxicity, to the best of our knowledge. The chemical modifications towards $\mathrm{Cu}(\mathrm{II})-\mathrm{A} \beta$ complexes include covalent adduct formation, oxidation, or both in a metal binding residue (His14)-specific manner and can be achieved using a rationally designed small molecule-based peptide modifier (L1). Our new rationale and molecular-level investigations of reactivities and mechanisms demonstrate the feasibility of developing effective strategies to regulate metal-interacting aggregation-prone peptides observed in neurodegenerative disorders. 


\section{INTRODUCTION}

Transition metals are essential for diverse functions in the brain, playing structural or catalytic roles in metalloproteins and neurotransmission. ${ }^{1-3}$ Among transition metals, copper is the third most abundant metal in the brain and an indispensable element for energy metabolism, antioxidant defense, and synthesis of neurotransmitters. ${ }^{4-8}$ Thus, the uptake and efflux of intracellular copper are tightly regulated in the healthy brain. ${ }^{4}$ When the homeostasis of copper is impaired, copper-mediated functions are disrupted, which could be further linked to the development of neurodegenerative disorders, such as Alzheimer's disease (AD) ${ }^{4-9}$

In the AD-afflicted brain, the level of copper is elevated as high as $400 \mu \mathrm{M}$ in senile plaques mainly composed of amyloid- $\beta$ (A $\beta$ ) aggregates. ${ }^{10,11}$ The complexation between $\mathrm{Cu}(\mathrm{II})$ and $\mathrm{A} \beta$ peptides, along with neurotoxic aspects of $\mathrm{Cu}(\mathrm{II})-\mathrm{A} \beta$ complexes, has been previously reported., ${ }^{4,-14}$ The binding affinity $\left(K_{d}\right)$ of $\mathrm{Cu}(I I)$ for $\mathrm{A} \beta$ peptides is in the picomolar to nanomolar range (ca. $10^{-11}$ to $10^{-7} \mathrm{M}$ ) with distinct coordination modes depending on $\mathrm{pH}^{4,14}$ The first coordination sphere of $\mathrm{Cu}(\mathrm{II})$ bound to $\mathrm{A} \beta$ typically consists of three nitrogen $(\mathrm{N})$ donor atoms and one oxygen $(\mathrm{O})$ donor atom. ${ }^{14,15}$ The $\mathrm{N}$ donor atoms are a combination of three histidine residues (i.e., His6, His13, and His14), an amide backbone, and the primary amine at the $\mathrm{N}$-terminus, while a carbonyl backbone between Asp1 and Ala2 is the $\mathrm{O}$ donor atom under physiological conditions. ${ }^{14-17} \mathrm{Cu}(\mathrm{II})$ binding to $A \beta$ can accelerate $A \beta$ aggregation and stabilize toxic structured $A \beta$ oligomers. ${ }^{4,18}$ In addition, redox-active $\mathrm{Cu}(\mathrm{I} / \mathrm{II})-\mathrm{A} \beta$ complexes can 
overproduce reactive oxygen species (ROS) via Fenton-like reactions, contributing towards oxidative stress..$^{4,11,19}$

To regulate the reactivities of $\mathrm{Cu}(\mathrm{II})-\mathrm{A} \beta$ complexes (i.e., aggregation and ROS generation), several metal chelators have been employed to remove $\mathrm{Cu}(\mathrm{II})$ from $\mathrm{Cu}(\mathrm{II})-$ $A \beta ; 20-22$ however, since the resultant metal-free $A \beta$ species upon dissociation of $\mathrm{Cu}(\mathrm{II})$ from $\mathrm{Cu}(\mathrm{II})-\mathrm{A} \beta$ complexes continued to aggregate generating toxic oligomers, the toxicity triggered by $A \beta$ species could not be fully controlled using metal chelators. Alternatively, a new class of small molecules was engineered as chemical reagents capable of forming a ternary complex with $\mathrm{Cu}(\mathrm{II})-\mathrm{A} \beta$ and consequently varying the reactivities of $\mathrm{Cu}(\mathrm{II})-\mathrm{A} \beta .^{23-25}$ These molecules, however, are not able to chelate $\mathrm{Cu}(\mathrm{II})$ out from $\mathrm{Cu}(\mathrm{II})-\mathrm{A} \beta$ complexes. To date, no chemical reagent or approach has been invented for sequestrating $\mathrm{Cu}(\mathrm{II})$ from $\mathrm{Cu}(\mathrm{II})-\mathrm{A} \beta$ and subsequently altering the onpathway oligomerization of the metal-free $A \beta$ produced upon removal of $\mathrm{Cu}(\mathrm{II})$ from $\mathrm{Cu}(\mathrm{II})-\mathrm{A} \beta$. To achieve these two aspects, modifying the coordination sphere of $\mathrm{Cu}(\mathrm{II})-$ $A \beta$ would be an effective tactic to disrupt $\mathrm{Cu}(\mathrm{II})$ binding to $\mathrm{A} \beta$ and obtain chemically modified metal-free $A \beta$, which could eventually modulate the aggregation and cytotoxicity of both $\mathrm{Cu}(\mathrm{II})-\mathrm{A} \beta$ and the resultant metal-free $\mathrm{A} \beta$.

Herein, for the first time, we report a novel mechanistic strategy for directly modifying the $\mathrm{Cu}(\mathrm{II})$ coordination site in $\mathrm{Cu}(\mathrm{II})-\mathrm{A} \beta$ complexes in a metal binding residue-specific manner (Figure 1a), to the best of our knowledge. The chemical modifications of $\mathrm{Cu}(\mathrm{II})-$ 
A $\beta$ complexes, achieved by our newly designed small molecule-based peptide modifier (L1; Figure 1b), include (i) the covalent bond formation between His14, a Cu(II)-binding amino acid residue in $A \beta,{ }^{14-17}$ and a structural fragment of L1 and (ii) the oxidation of His14 into 2-oxohistidine. Such modifications are demonstrated to effectively block $\mathrm{Cu}(\mathrm{II})-\mathrm{A} \beta$ complexation and control the aggregation and toxicity of both $\mathrm{Cu}(\mathrm{II})-\mathrm{A} \beta$ and the resultant metal-free $A \beta$. Collectively, our overall approaches and findings would contribute to the development of new effective strategies to regulate metal-interacting amyloidogenic peptides associated with neurodegeneration through directly modifying their metal coordination sites.

\section{RESULTS AND DISCUSSION}

Rational Design and Characterization of a Small Molecule as a Peptide Modifier for the $\mathrm{Cu}$ (II) Coordination Site in Cu(II)-A $\beta$ Complexes. A small molecule (L1) was rationally devised as a peptide modifier capable of transforming the $\mathrm{Cu}(\mathrm{II})$-binding amino acid residues in $A \beta$ (Figure 1a; covalent adduct formation and oxidation). For the design of L1 (Figure 1b), two structural moieties, i.e., thiophen-2-ylmethanamine and $\mathrm{N}, \mathrm{N}$-dimethylaniline (DMA), were incorporated into a structural entity for interactions with $\mathrm{Cu}(\mathrm{II})$ and $\mathrm{A} \beta$, respectively. The $\mathrm{C}-\mathrm{N}$ bond attached to DMA at the para position in L1 could be hydrolytically cleaved in the presence of $\mathrm{Cu}(\mathrm{II})-\mathrm{A} \beta,{ }^{25-27}$ generating thiophen-2-ylmethanol (TM) and N,N-dimethyl-p-phenylenediamine (DMPD), as depicted in Scheme 1 (i) and (ii). Both fragments (TM and DMPD ${ }^{28}$ ) could be conjugated with $A \beta$ that contains multiple nucleophilic amino acid residues (e.g., His, Lys, and Tyr). In addition to L1's fragmentation, the oxidation of $\mathbf{L} 1$ to $\mathbf{L 1}^{+\bullet}$ can occur while $\mathrm{Cu}(\mathrm{II})-\mathrm{A} \beta$ 
is reduced to $\mathrm{Cu}(\mathrm{I})-\mathrm{A} \beta$ as shown in Scheme (iii) (vide infra, oxidation potential). ${ }^{25,29}$ $\mathrm{Cu}(\mathrm{I})-\mathrm{A} \beta$ can undergo the reaction with dioxygen $\left(\mathrm{O}_{2}\right)$ affording $A \beta$ oxidation under aerobic conditions. ${ }^{12,30-32}$ In addition, a cationic radical form of L1 could abstract a hydrogen atom from $A \beta$ producing a carbon-centered peptide radical which is able to react with $\mathrm{O}_{2}$ leading to peptide oxidation. ${ }^{30,33,34}$ Together, the small molecule, $\mathbf{L} \mathbf{1}$, is rationally engineered to carry out (i) the covalent conjugation of its structural fragment with $A \beta$ as well as (ii) the oxidation of $A \beta$ at the $C u(I I)$-binding site (i.e., His 14; vide infra). These peptide modifications towards $\mathrm{Cu}(\mathrm{II})-\mathrm{A} \beta$ are able to impact the aggregation and toxicity of $\mathrm{Cu}(\mathrm{II})-\mathrm{A} \beta$ and the resultant metal-free $A \beta$ through disrupting $\mathrm{Cu}(\mathrm{II})-\mathrm{A} \beta$ binding and generating chemically transformed metal-free $A \beta$.

To confirm whether the structural transformations of L1 (i.e., hydrolytic cleavage and oxidation; Scheme 1) can be responsible for modifications of the coordination sphere of $\mathrm{Cu}(\mathrm{II})-\mathrm{A} \beta$, two additional compounds, $\mathbf{L} 2$ and $\mathbf{L} 3$, were constructed through the replacement of the $\mathrm{C}-\mathrm{N}$ bond of $\mathrm{L} 1$ with the $\mathrm{C}-\mathrm{S}$ bond, as presented in Figure $1 \mathrm{~b}$. Similar to L1, L2 and L3 contain DMA for $A \beta$ interaction $^{25-27}$ and a thiophen-2ylmethanethioether group (for L2) or a pyridin-2-ylmethanethioether group (for L3) for metal interaction; thus, they could interact with $\mathrm{Cu}(\mathrm{II})-\mathrm{A} \beta$. On the other hand, $\mathrm{Cu}(\mathrm{II})$ - or $\mathrm{Cu}(\mathrm{II})-\mathrm{A} \beta$-mediated $\mathrm{S}_{\mathrm{N} 2}$-type cleavage of $\mathbf{L 2}$ and $\mathbf{L} 3$ is relatively harder than that of $\mathbf{L 1}$ since the $p$-aminothiophenol moiety in their overall structures shows its higher oxidation potential than DMPD ${ }^{29}$ thus serving as a poor leaving group. In addition, the redox property of the $p$-aminothiophenol moiety would make L2 and L3 harder to undergo 
one-electron oxidation compared to L1. Overall, L1's transformations could be validated to be critical for its reactivity against $\mathrm{Cu}(\mathrm{II})-\mathrm{A} \beta$ complexes via the studies of $\mathbf{L} 2$ and $\mathbf{L} 3$.

As summarized in Scheme S1, L1-L3 were prepared through reductive amination (for L1) and substitution reactions (for L2 and L3). More detailed information for the synthesis and characterization of L1-L3 is provided in the Supporting Information (Scheme S1 and Figures S1-S3). L1-L3 are expected to cross the blood-brain barrier (BBB) $[\operatorname{logBB}=0.345$ (for L1), 0.702 (for L2), and 0.338 (for L3)] adhering to the values of Lipinski's rule (Table S1). ${ }^{35,36}$ Furthermore, the in vitro parallel artificial membrane permeability assay adapted for BBB (PAMPA-BBB) was employed to obtain the experimental permeability values $\left(-\log P_{\mathrm{e}}\right)$ of the compounds. The values of $-\log P_{\mathrm{e}}$ of compounds were 4.31 (for L1), 4.61 (for L2), and 4.35 (for L3), indicating the possible availability of these small molecules in the central nervous system (Table S1). ${ }^{35,36}$

Modifications of the Coordination Sphere of Cu(II)-A $\beta$ Complexes by L1. Chemical variations at the $\mathrm{Cu}(\mathrm{II})$ coordination site in $\mathrm{Cu}(\mathrm{II})-\mathrm{A} \beta$ complexes by $\mathrm{L} 1$ were identified by electrospray ionization-mass spectrometry (ESI-MS) and tandem MS (ESI-MS²). When $A \beta_{40}$ was incubated with $\mathrm{Cu}(\mathrm{II}), \mathrm{Cu}(\mathrm{II})$-bound $A \beta_{40}$ was detected in the $\mathrm{ESI}-\mathrm{MS}$ spectrum (Figure 2a; left). Upon treatment of $\mathrm{Cu}(\mathrm{II})$-treated $\mathrm{A} \beta_{40}$ with $\mathrm{L1}$, distinctive peptide modifications, i.e., covalent conjugation and oxidation, were indicated, along with the disappearance of the peak corresponding to $\mathrm{Cu}(\mathrm{II})-\mathrm{A} \beta_{40}$ (Figure 2a; right), while L2 and L3 did not noticeably affect $\mathrm{Cu}(\mathrm{II})$ binding to $\mathrm{A} \beta_{40}$ (Figure S4). In the absence of $\mathrm{Cu}(\mathrm{II})$, modifications of metal-free $A \beta_{40}$ were not observed by L1-L3 (Figure S5). 
(i) Covalent Adduct Formation between $A \beta$ and the Fragmented L1. Under $\mathrm{Cu}(\mathrm{II})-$ present conditions, a covalent adduct between $A \beta_{40}$ and the structural portion of the fragmented L1 was observed at $1476 \mathrm{~m} / \mathrm{z}$ with a mass shift of $94 \mathrm{Da}$, relative to metalfree $A \beta_{40}(1443 \mathrm{~m} / z)$ (Figure 2a). This peak is assigned to be a conjugation of $A \beta_{40}$ with 2-methylthiophene (98 Da) followed by the loss of four protons [Scheme 1 (i)]. Moreover, the peak of $\mathrm{Cu}(\mathrm{II})$-bound $A \beta_{40}$ disappeared as $\mathrm{L} 1$ was introduced into $\mathrm{Cu}(\mathrm{II})$-added $A \beta_{40}$ (Figure 2a), implying that $\mathrm{Cu}(\mathrm{II})-\mathrm{A} \beta$ complexation could be disrupted through the covalent bonding between $A \beta_{40}$ and 2-methylthiophene.

As shown in Scheme 1 (i) and (ii), L1 can be hydrolytically cleaved to TM and DMPD in the presence of $\mathrm{Cu}(\mathrm{II})-\mathrm{A} \beta$ based on previously reported studies. ${ }^{25}$ When TM interacts with $\mathrm{Cu}(\mathrm{II})$ surrounded by $\mathrm{A} \beta$, it possibly forms a transient ternary $\mathrm{TM}-\mathrm{Cu}(\mathrm{II})-\mathrm{A} \beta$ complex. In addition, TM bound to the $\mathrm{Cu}(\mathrm{II})$ center in the transient ternary complex could be first attacked by a nucleophilic amino acid residue in $A \beta$ (e.g., His; vide infra) producing a covalent bond between $A \beta$ and the 2-methylthiophene moiety with the dissociation of $\mathrm{Cu}(\mathrm{II})$ from $\mathrm{Cu}(\mathrm{II})-\mathrm{A} \beta$. A second nucleophilic attack on thiophene, after possible epoxidation of thiophene in the $A \beta$ covalently bound to 2-methylthiophene, ${ }^{37,38}$ could afford a covalent adduct with $A \beta$ as the final product with the addition of $94 \mathrm{Da}$ to native $A \beta\left[\right.$ Scheme 1 (i)]. ${ }^{39}$

To support whether the fragmentation of L1 to TM is necessary for its covalent linkage to $\mathrm{Cu}(\mathrm{II})$-treated $\mathrm{A} \beta$, the $\mathrm{TM}$-added $\mathrm{Cu}(\mathrm{II})-\mathrm{A} \beta$ sample was further analyzed by $\mathrm{ESI}-\mathrm{MS}$ 
(Figure $2 b$ ). Similar to $L 1$, the peak corresponding to $\left[A \beta_{40}+94\right]^{3+}$ was detected at 1476 $m / z$ in the sample incubated with TM, along with the suppression of the peak assigned as $\mathrm{Cu}(\mathrm{II})$-bound $A \beta_{40}$, indicative of generating a covalent adduct of $A \beta_{40}$ with 2methylthiophene. Thus, the covalent bond formation with $A \beta_{40}$ observed upon introduction of $\mathbf{L} 1$ requires the molecule's fragmentation affording TM.

(ii) Oxidation of $\mathrm{Cu}(\mathrm{II})$-Treated $\mathrm{A} \beta$ by $L 1$. In addition to a covalent adduct of $\mathrm{A} \beta_{40}$ with L1's structural fragment, a mass shift of monomeric $A \beta_{40}$ was observed by $16 \mathrm{Da}$ at $1449 \mathrm{~m} / \mathrm{z}$ corresponding to the singly oxidized $\mathrm{A} \beta_{40}$ monomer upon incubation of $\mathrm{Cu}(\mathrm{II})-$ added $A \beta_{40}$ with L1 (Figure 2a; red peak). $C u(I I)-A \beta$ could be reduced to $C u(I)-A \beta$ (ca. $0.08 \mathrm{~V}$ versus $\mathrm{Ag} / \mathrm{AgCl}$ in $\mathrm{H}_{2} \mathrm{O}$ ) upon L1's oxidation to the cationic radical, $\mathbf{L 1}^{+\bullet}$ (Scheme 1), considering the $E_{p a}$ value of the $p$-diaminobenzene moiety in L1 (ca. $0.1 \mathrm{~V}$ versus $\mathrm{Ag} / \mathrm{AgCl}$ in $\left.\mathrm{H}_{2} \mathrm{O}\right) \cdot{ }^{29,40,41} \mathrm{Cu}(\mathrm{I})-\mathrm{A} \beta$ then reacts with $\mathrm{O}_{2}$ forming $\mathrm{Cu}(\mathrm{II})\left(\mathrm{A} \beta_{40}\right)\left(\mathrm{O}_{2}{ }^{--}\right)$and $\mathrm{Cu}(\mathrm{II})\left(\mathrm{A} \beta_{40}\right)\left(\mathrm{O}_{2}{ }^{2-}\right)$ intermediates under aerobic conditions [Scheme 1 (iii), top], which could lead to $A \beta$ oxidation. ${ }^{12,30-32}$ In parallel, L1+• could abstract a hydrogen atom from A $\beta$ to generate a carbon-centered peptide radical, which could further interact with $\mathrm{O}_{2}$ to produce a peroxyl radical form of $A \beta$ [Scheme 1 (iii), bottom].$^{33}$ L1-induced $A \beta$ oxidation site in the presence of $\mathrm{Cu}(\mathrm{II})$ was assigned to be His14 (vide infra). Such His oxidation could affect $\mathrm{Cu}(\mathrm{II})$ binding to $\mathrm{A} \beta$, supported by the decrease in the peak intensity of $\mathrm{Cu}(\mathrm{II})-\mathrm{A} \beta$ (Figure $2 a)$. To determine the fragmentation of $\mathbf{L 1}$ is a prerequisite process for $A \beta$ oxidation, the sample containing $T M, C u(I I)$, and $A \beta_{40}$ was analyzed. $A \beta_{40}$ oxidation, however, was not observed in this sample (Figure $2 b$ ), suggesting that 
such peptide oxidation occurs through L1's oxidation in the presence of $\mathrm{Cu}(\mathrm{II})-\mathrm{A} \beta$ rather than the compound's fragmentation into TM and DMPD (Scheme 1).

(iii) Concurrent Modifications of His14 in $\mathrm{Cu}(\mathrm{II})-\mathrm{A} \beta$ by L1: Covalent Adduct Formation and Oxidation. As depicted in Figure 2a, the singly oxidized covalent adduct was detected at $1481 \mathrm{~m} / \mathrm{z}$ assigned as $\left[\mathrm{A} \beta_{40}+94+\mathrm{O}\right]^{3+}$, along with a covalent adduct of L1's structural fragment with $A \beta_{40}$ and the singly oxidized $A \beta_{40}$. This observation indicates that both the covalent adduct formation with $A \beta$ and $A \beta$ oxidation can concurrently occur when $\mathrm{Cu}(\mathrm{II})-\mathrm{A} \beta$ reacts with L1. In addition, the reduced peak intensity of the $\mathrm{Cu}(\mathrm{II})-\mathrm{A} \beta_{40}$ complex shown in Figure 2a supports the disruption of $\mathrm{Cu}(\mathrm{II})-\mathrm{A} \beta$ complexation by these modifications of $\mathrm{A} \beta$.

To identify which metal-binding residue is chemically modified by L1, ESI-MS ${ }^{2}$ was carried out for the singly oxidized covalent adduct monitored at $1481 \mathrm{~m} / \mathrm{z}$ (Figure 2c). The collision-induced dissociation (CID) on the selected ion produces $b$ fragments useful for analyzing residue-specific modifications of peptides. ${ }^{29}$ As indicated in Figure 2c, the 94 Da-added $b$ fragments were observed from $b_{14}$, suggesting that the His 14 residue in $A \beta_{40}$ could be the first nucleophile capable of reacting with TM to generate a covalent adduct [Scheme 1 (i)]. In addition, the oxidized $b$ fragments were detected from $b_{14}$, indicating His14 as a plausible oxidation site in $A \beta$. Lastly, the singly oxidized covalent adducts on $b$ fragments were also monitored from $b_{14}$. This observation confirms that the modifications of $\mathrm{Cu}(\mathrm{II})-\mathrm{A} \beta_{40}$ by $\mathbf{L} \mathbf{1}$ occur at His14. Collectively, $\mathbf{L} \mathbf{1}$ is able to chemically modify the metal-binding residue, His14, disrupting the complexation 
between $\mathrm{Cu}(\mathrm{II})$ and $\mathrm{A} \beta$ and affording structural variations of the resultant metal-free $A \beta$, i.e., (i) covalent bond formation and (ii) oxidation. These modifications of $\mathrm{Cu}(\mathrm{II})-\mathrm{A} \beta$ at His 14 could significantly affect the aggregation and cytotoxicity of $\mathrm{Cu}(\mathrm{II})-\mathrm{A} \beta$ and the resultant metal-free $A \beta$ (vide infra).

$\mathrm{Cu}$ (II)-A $\beta$-Mediated Transformations of L1. To determine the molecular mechanisms for L1-mediated modifications at the $\mathrm{Cu}(\mathrm{II})$ coordination site in $\mathrm{Cu}(\mathrm{II})-\mathrm{A} \beta$ complexes, the transformations of $\mathbf{L} 1-\mathbf{L} 3$ were investigated in detail in the presence of $\mathrm{Cu}(\mathrm{II})$ and/or $A \beta$ (Figures 3 and 4$)$.

(i) Cleavage of $\mathbf{L 1}$. The covalent adduct formation with $A \beta_{40}$ is directed by $\mathbf{L} 1$ 's transformation, as shown in Figure $2 \mathrm{~b}$. The fragmentation of L1 into TM and DMPD in the presence of $\mathrm{Cu}(\mathrm{II})$ with or without $\mathrm{A} \beta_{40}$ was monitored by UV-vis and ESI-MS. When L1 was incubated with $\mathrm{CuCl}_{2}$ and $\mathrm{A} \beta_{40}$ (Figure 3a; left), an increase in absorbance at ca. $375 \mathrm{~nm}$ was observed followed by the disappearance of the same peak after $12 \mathrm{~h}$. This charge transfer band suggests the possible interaction between L1 and $\mathrm{Cu}(\mathrm{II}) .{ }^{42}$ Additionally, the peaks at ca. 260 and $300 \mathrm{~nm}$ were slightly enhanced, which may result from the presence of a mixture of TM and DMPD. As depicted in Figure 4, DMPD, one of L1's cleaved products, was also detected in the ESI-MS spectrum when $\mathbf{L} 1$ was treated to $\mathrm{Cu}(\mathrm{II})-\mathrm{A} \beta_{40}$.

Under $A \beta_{40}$-free conditions (Figure $3 a$, right), the optical bands of $\mathrm{Cu}(\mathrm{II})$-treated $\mathbf{L} \mathbf{1}$ at 260 and $300 \mathrm{~nm}$ were noticeably enhanced, suggesting the production of both TM and 
DMPD. The $\mathrm{Cu}(\mathrm{II})$-induced fragmentation of $\mathrm{L} 1$ without $A \beta$ was also confirmed by $\mathrm{ESI}-$ MS (Figure S6a). Different from L1, L2 and L3 did not show their noticeable transformation in the presence of $\mathrm{Cu}(\mathrm{II})$ and $\mathrm{Cu}(\mathrm{II})-\mathrm{A} \beta$, except for the charge transfer band in the range of ca. 300 to $500 \mathrm{~nm}$ (Figures $3 \mathrm{~b}$ and S6b). This observation supports no modification at the $\mathrm{Cu}(\mathrm{II})$ coordination site in $\mathrm{Cu}(\mathrm{II})-\mathrm{A} \beta$ by these two compounds (Figure S4).

(ii) Oxidation of L1. A $\beta$ oxidation shown in Figure $2 b$ could occur through L1's oxidation into $\mathrm{L1}^{+\bullet}$ in the presence of $\mathrm{Cu}(\mathrm{II})-\mathrm{A} \beta_{40}$. When $\mathrm{L1}$ was treated with $\mathrm{Cu}(\mathrm{II})-\mathrm{A} \beta_{40}$, the relatively unstable cationic radical intermediate, $\mathbf{L 1}^{+*}$, was not detected by either $\mathrm{ESI}-$ MS or UV-vis (Figures 3a and 4). Instead, the two-electron oxidized form $\left(\mathrm{L1}^{+}\right)$was monitored in the low molecular weight region of the ESI-MS spectrum from the L1containing $\mathrm{Cu}(\mathrm{II})-\mathrm{A} \beta_{40}$ sample (Figure $4 ; \mathbf{M}_{\mathrm{v}}{ }^{+}$). The observed transformation of $\mathbf{L 1}$ suggests that $A \beta$ oxidation is linked to the redox communication between of $L 1$ and $\mathrm{Cu}(\mathrm{II})-\mathrm{A} \beta\left[\right.$ Scheme 1 (iii)]. ${ }^{12}$

In the presence of $\mathrm{Cu}(\mathrm{II})$ without $\mathrm{A} \beta_{40}$, the peak at $232 \mathrm{~m} / \mathrm{z}$ corresponding to $\mathrm{L1}^{+\boldsymbol{*}}$ was detected by ESI-MS (Figure S6a). Moreover, the peaks at ca. 500 and $550 \mathrm{~nm}$ were exhibited when L1 and $\mathrm{Cu}(\mathrm{II})$ were co-incubated, indicative of the one-electron oxidation of the compound (Figure 3a, right). ${ }^{28,29}$ Note that these double peaks may be resulted from DMPD+• produced one-electron oxidation of DMPD ${ }^{28,43}$ (one of L1's fragmented products shown in Scheme 1), ${ }^{28,43}$ which may be also involved in A $\beta$ oxidation. In the case of L2 and L3, their spectral changes at ca. 500 and $550 \mathrm{~nm}$ were not presented 
even in the presence of $\mathrm{Cu}(\mathrm{II})$ with or without $A \beta$, suggesting no $\mathrm{Cu}(\mathrm{II})$-mediated oxidation of these two compounds (Figures $3 b$ and S6b).

In addition to the spectroscopic and spectrometric studies, the oxidation potentials $\left(E_{p a}\right)$ of L1-L3 were measured at various scan rates in DMSO and $\mathrm{H}_{2} \mathrm{O}$ (Figures 3c, S7, and S8). The $\mathrm{E}_{\mathrm{pa}}$ value of $\mathbf{L} 1$ was determined as $0.267 \mathrm{~V}$ (versus $\mathrm{Ag} / \mathrm{AgCl}$ in DMSO; Figure S7), which is much lower than those of $\mathbf{L} 2(0.770 \mathrm{~V})$ and $\mathbf{L} 3(0.787 \mathrm{~V})$. On the basis of their $E_{p a}$ values, the $p$-diaminobenzene group is responsible for stabilizing the oxidized form of $\mathbf{L 1}$, consistent with the previously reported molecules. ${ }^{25,29}$ The $E_{p a}$ values of $\mathbf{L} 1$ and L3 were also obtained in $\mathrm{H}_{2} \mathrm{O}[0.131 \mathrm{~V}$ (for L1) and 0.538 (for L3) versus Ag/AgCl; Figure S8]. Note that the $E_{p a}$ value of $\mathbf{L 2}$ could not be measured in $\mathrm{H}_{2} \mathrm{O}$ because of its limited solubility. Based on the reduction potential of $C u(I)-A \beta_{42}$ to $C u(I)-A \beta_{42}$ (ca. 0.08 V versus $\mathrm{Ag} / \mathrm{AgCl}$ in $\left.\mathrm{H}_{2} \mathrm{O}\right),{ }^{41}$ the oxidation potential of $\mathrm{L} 1$ is low enough to reduce $\mathrm{Cu}(\mathrm{II})-$ $A \beta$ to $C u(I)-A \beta$.

Taken together, $\mathrm{Cu}(\mathrm{II})-$ or $\mathrm{Cu}(\mathrm{II})-\mathrm{A} \beta$-mediated cleavage of the $\mathrm{C}-\mathrm{N}$ bond in $\mathrm{L} 1$ takes place to generate TM and DMPD [Scheme 1 (i)]. The fragmentation of L1 into TM is needed for the covalent bond formation with $A \beta$ in the presence of $\mathrm{Cu}(\mathrm{II})$. Furthermore, L1, relatively easily oxidized with the redox chemistry of $\mathrm{Cu}(\mathrm{I} / \mathrm{II})-\mathrm{A} \beta$, is able to induce the oxidation of His14 to produce 2-oxohistidine [Scheme 1 (iii)]. In both L2 and L3 that contain the $\mathrm{C}-\mathrm{S}$ bond over the $\mathrm{C}-\mathrm{N}$ bond, as shown in Figure 1, such transformations (i.e., fragmentation and oxidation) observed in L1 were not indicated. The chemical modifications of $\mathrm{Cu}(\mathrm{II})-\mathrm{A} \beta$ complexes through L1's transformations could, as expected, 
vary the aggregation pathways and cytotoxicity of $\mathrm{Cu}(\mathrm{II})-\mathrm{A} \beta$ and the resultant metalfree $A \beta$ (vide infra).

Modulation of the Aggregation Pathways of $\mathbf{C u}(\mathrm{II})-\mathbf{A} \beta$ by L1. To determine whether L1-induced modifications at the $\mathrm{Cu}$ (II) coordination site (i.e., covalent adduct formation and oxidation) affect the aggregation pathways of $\mathrm{Cu}(\mathrm{II})-\mathrm{A} \beta$, the size distribution and morphology of the resultant $A \beta$ species were verified by gel electrophoresis with Western blotting (gel/Western blot) and transmission electron microscopy (TEM), respectively. Two types of experiments were conducted: (i) in inhibition experiments (Figures $5 a$ and S11), freshly prepared $A \beta$ monomers were incubated with L1-L3 in the presence and absence of $\mathrm{Cu}(\mathrm{II})$ for $24 \mathrm{~h}$; (ii) in disaggregation experiments (Figures $\mathrm{S9}$ and S12), $A \beta$ peptides are first pre-incubated with or without $\mathrm{Cu}(\mathrm{II})$ for $24 \mathrm{~h}$ followed by treatment with L1-L3 for an additional $24 \mathrm{~h}$.

In the inhibition experiments, the aggregation pathways of both $\mathrm{Cu}(\mathrm{II})-\mathrm{A} \beta_{40}$ and $\mathrm{Cu}(\mathrm{II})-$ $\mathrm{A} \beta_{42}$ were altered by L1 (Figures 5 and S11). When L1 was incubated with $\mathrm{Cu}(\mathrm{II})-$ treated $A \beta$ species, noticeable smearing bands were indicated in the gel/Western blots, compared to those obtained with compound-free $\mathrm{Cu}(\mathrm{II})-\mathrm{A} \beta$ samples (Figure $5 \mathrm{~b}$; left). The resultant $A \beta$ aggregates produced in the presence of L1 from the inhibition experiments, visualized by TEM, were observed to be shorter and smaller, relative to compound-free $\mathrm{Cu}(\mathrm{II})-\mathrm{A} \beta$ samples (Figures $5 \mathrm{c}$ and S11). Aggregation of metal-free $A \beta_{40}$ and $A \beta_{42}$ was not affected in the presence of $\mathbf{L 1}$, confirmed by the gel/Western (no smearing bands; Figure 5b; right) and TEM (no morphological change; Figures $5 \mathrm{c}$ and 
S11). As expected from no transformation of the compounds under our experimental conditions, L2 and L3 were not able to alter the aggregation pathways of both $\mathrm{Cu}(\mathrm{II})-$ added $A \beta_{40} / A \beta_{42}$ and metal-free $A \beta_{40} / A \beta_{42}$ based on the results obtained by gel/Western blots and TEM (Figures 5b, 5c, and S11).

The disassembly or modulation of further aggregation of preformed $\mathrm{Cu}(\mathrm{II})$-treated and metal-free $A \beta$ aggregates by L1-L3 was also investigated (Figures S9 and S12). Similar to the inhibition studies, the gel/Western blots showed (i) the alteration of the aggregation pathways of preformed $\mathrm{Cu}(\mathrm{II})$-treated $A \beta_{40}$ and $A \beta_{42}$ aggregates in the presence of L1; (ii) no influence on metal-free $A \beta_{40}$ and $A \beta_{42}$ aggregates by L1 (Figures S9b). In the TEM images, short fibrillar $A \beta$ aggregates were monitored upon treatment of preformed $\mathrm{Cu}(\mathrm{II})-\mathrm{A} \beta$ aggregates with $\mathbf{L} \mathbf{1}$, while long and large $A \beta$ fibrils were still found under metal-free conditions (Figures S9c and S12). Moreover, L2 and L3 exhibited no effects towards the aggregation of preformed $\mathrm{Cu}(\mathrm{II})-\mathrm{A} \beta_{40} / \mathrm{A} \beta_{42}$ and metalfree $A \beta_{40} / A \beta_{42}$ aggregates according to gel/Western blot and TEM studies (Figures S9 and S12). Overall, the aggregation of both $\mathrm{Cu}(\mathrm{II})-\mathrm{A} \beta_{40}$ and $\mathrm{Cu}(\mathrm{II})-\mathrm{A} \beta_{42}$ over metal-free $A \beta$ aggregation is noticeably modulated by $\mathbf{L} 1$, while $\mathbf{L} 2$ and $\mathbf{L} 3$ cannot significantly affect the aggregation of both $\mathrm{Cu}(\mathrm{II})$-added and metal-free $\mathrm{A} \beta$. These observations demonstrate that the metal binding residue-specific chemical modifications of $\mathrm{Cu}(\mathrm{II})-$ $A \beta$ by treatment of $L 1$ are able to notably impact the aggregation pathways of $\mathrm{Cu}(\mathrm{II})-$ $A \beta$ and the metal-free $A \beta$ produced from removal of $\mathrm{Cu}(\mathrm{II})$ from $\mathrm{Cu}(\mathrm{II})-\mathrm{A} \beta$. 
Regulation of $\mathrm{Cu}(\mathrm{II})-\mathrm{A} \beta$-Induced Toxicity and Free Radicals by L1. To identify if the metal binding residue-specific modifications of $\mathrm{Cu}(\mathrm{II})-\mathrm{A} \beta$ complexes affect $\mathrm{Cu}(\mathrm{II})-\mathrm{A} \beta$ induced toxicity in living cells, cell studies employing the human neuroblastoma $\mathrm{SH}$ SY5Y (5Y) cell line were conducted. $5 Y$ cells were incubated with $A \beta_{40}, \mathbf{C u C l}_{2}$, and $\mathbf{L} 1$ for $24 \mathrm{~h}$, and their survival was determined by the MTT assay [MTT $=3-(4,5-$ dimethylthiazol-2-yl)-2,5-diphenyltetrazolium bromide]. The cell viability of $\mathrm{Cu}(\mathrm{II})$ treated $A \beta$ was improved by ca. $25 \%$ in the presence of $L 1$, relative to that of compoundfree $\mathrm{Cu}(\mathrm{II})-\mathrm{A} \beta$ (Figure $6 \mathrm{a}$ ), indicating that L1-induced modifications of $\mathrm{Cu}(\mathrm{II})-\mathrm{A} \beta$ complexes at His 14 could alleviate the toxicity triggered by $\mathrm{Cu}(\mathrm{II})-\mathrm{A} \beta$ complexes. Note that our compounds (L1-L3) are relatively less toxic under the conditions used for this work (> $80 \%$ of cell survival up to $25 \mu \mathrm{M}$ ) (Figure S13).

Furthermore, the regulation of free organic radicals by L1-L3 was monitored by the Trolox equivalent antioxidant capacity (TEAC) assay, ${ }^{44}$ since $\mathrm{Cu}(\mathrm{II})-\mathrm{A} \beta$ complexes can produce free radicals in the AD-affected brain (Figure $6 \mathrm{~b}$; left). ${ }^{11,19}$ The TEAC values of small molecules indicate their ability to quench free radicals [e.g., ABTS ${ }^{+*} ; A B T S=2,2^{\prime}-$ azino-bis(3-ethylbenzothiazoline-6-sulfonic acid)], relative to that of Trolox (6-hydroxy2,5,7,8-tetramethylchroman-2-carboxylic acid), a vitamin E analogue. The TEAC value of L1 was $1.86( \pm 0.10)$, presenting the compound as a better scavenger against free organic radicals than Trolox. The TEAC values of L2 and L3 were $0.86( \pm 0.10)$ and $0.96( \pm 0.13)$, similar to those of Trolox. The trend of the compounds' antioxidant properties is highly correlated to their $E_{p a}$ values (Figure 6b; right). L1 with a relatively low $E_{p a}$ value exhibited a relatively high TEAC value. These observations are consistent 
with the previous reports regarding a direct relation between redox properties of compounds and their antioxidant activity. ${ }^{29,45}$

\section{CONCLUSIONS}

An effective and straightforward mechanistic approach was developed for chemically modifying the coordination sphere of $\mathrm{Cu}(\mathrm{II})-\mathrm{A} \beta$ complexes in a metal binding residuespecific manner. The modifications (i.e., covalent adduct formation and oxidation at a $\mathrm{Cu}(\mathrm{II})$-binding amino acid residue, His14) were achieved using a rationally engineered small molecule-based peptide modifier (L1). The chemical modifications at the metalbinding residue, His14, are able to (i) block the complexation between $\mathrm{Cu}(\mathrm{II})$ and $\mathrm{A} \beta$ and (ii) alter the aggregation characteristics of both $\mathrm{Cu}(\mathrm{II})-\mathrm{A} \beta$ and the resultant $\mathrm{Cu}(\mathrm{II})-$ free $A \beta$ species, producing less toxic $A \beta$ species. Our molecular-level mechanistic investigations propose that such modifications in the coordination sphere of $\mathrm{Cu}(\mathrm{II})-\mathrm{A} \beta$ complexes occur through the transformation of $\mathbf{L} 1$ in the presence of $\mathrm{Cu}(\mathrm{II})-\mathrm{A} \beta$. Previous studies have introduced peptide modifications to a broad range of $A \beta$ or other amyloidogenic peptides to regulate their aggregation pathways; ${ }^{46-48}$ however, no example was reported for directly modifying the coordination sphere of metal-peptide complexes. Our overall multidisciplinary studies with emphasis on novel strategic design, reactivities, and mechanisms demonstrate the validity of developing rational mechanistic tactics for modulating metal-interacting aggregation-prone peptides or proteins related to the pathologies of neurodegenerative disorders.

\section{ASSOCIATED CONTENT}


The Supporting Information is available free of charge on the ACS Publications website. Experimental Section, Scheme S1, Tables S1-S3, and Figures S1-S13 (PDF)

\section{AUTHOR INFORMATION \\ Corresponding Author}

*miheelim@kaist.ac.kr

\section{ORCID}

Mi Hee Lim: 0000-0003-3377-4996

\section{Notes}

The authors declare no competing financial interest.

\section{ACKNOWLEDGMENTS}

This work was supported by the National Research Foundation of Korea (NRF) grant funded by the Korean government [NRF-2016R1A5A1009405 and NRF2017R1A2B3002585 (to M.H.L.); NRF-2015R1D1A1A01060188 (to J.C.)]; KAIST (to M.H.L.). We thank Geewoo Nam for assistance in initial manuscript writing.

\section{REFERENCES}

(1) Que, E. L.; Domaille, D. W.; Chang, C. J. Metals in neurobiology: probing their chemistry and biology with molecular imaging. Chem. Rev. 2008, 108, 15171549. 
(2) Savelieff, M. G.; Nam, G.; Kang, J.; Lee, H. J.; Lee, M.; Lim, M. H. Development of multifunctional molecules as potential therapeutic candidates for Alzheimer's disease, Parkinson's disease, and amyotrophic lateral sclerosis in the last decade. Chem. Rev. 2019, 119, 1221-1322.

(3) Chang, C. J. Searching for harmony in transition-metal signaling. Nat. Chem. Biol. 2015, 11, 744-747.

(4) Kepp, K. P. Bioinorganic chemistry of Alzheimer's disease. Chem. Rev. 2012, $112,5193-5239$.

(5) Barnham, K. J.; Masters, C. L.; Bush, A. I. Neurodegenerative diseases and oxidative stress. Nat. Rev. Drug Discov. 2004, 3, 205-214.

(6) Hung, Y. H.; Bush, A. I.; Cherny, R. A. Copper in the brain and Alzheimer's disease. J. Biol. Inorg. Chem. 2010, 15, 61-76.

(7) Scheiber, I. F.; Mercer, J. F. B.; Dringen, R. Metabolism and functions of copper in brain. Prog. Neurobiol. 2014, 116, 33-57.

(8) Nam, E.; Han, J.; Suh, J.-M.; Yi, Y.; Lim, M. H. Link of impaired metal ion homeostasis to mitochondrial dysfunction in neurons. Curr. Opin. Chem. Biol. 2018, 43, 8-14.

(9) Bush, A. I.; Masters, C. L.; Tanzi, R. E. Copper, $\beta$-amyloid, and Alzheimer's disease: tapping a sensitive connection. Proc. Natl. Acad. Sci. U. S. A. 2003, 100, 11193-11194.

(10) Hureau, C.; Faller, P. A $\beta$-mediated ROS production by $\mathrm{Cu}$ ions: structural insights, mechanisms and relevance to Alzheimer's disease. Biochimie 2009, 91, $1212-1217$. 
(11) Smith, D. G.; Cappai, R.; Barnham, K. J. The redox chemistry of the Alzheimer's disease amyloid $\beta$ peptide. Biochim. Biophys. Acta 2007, 1768, 1976-1990.

(12) Savelieff, M. G.; Lee, S.; Liu, Y.; Lim, M. H. Untangling amyloid- $\beta$, tau, and metals in Alzheimer's disease. ACS Chem. Biol. 2013, 8, 856-865.

(13) Faller, P.; Hureau, C.; Berthoumieu, O. Role of metal ions in the self-assembly of the Alzheimer's amyloid- $\beta$ peptide. Inorg. Chem. 2013, 52, 12193-12206.

(14) Kepp, K. P. Alzheimer's disease: how metal ions define $\beta$-amyloid function. Coord. Chem. Rev. 2017, 351, 127-159.

(15) Drew, S. C.; Noble, C. J.; Masters, C. L.; Hanson, G. R.; Barnham, K. J. Pleomorphic copper coordination by Alzheimer's disease amyloid- $\beta$ peptide. J. Am. Chem. Soc. 2009, 131, 1195-1207.

(16) Lee, S. J. C.; Nam, E.; Lee, H. J.; Savelieff, M. G.; Lim, M. H. Towards an understanding of amyloid- $\beta$ oligomers: characterization, toxicity mechanisms, and inhibitors. Chem. Soc. Rev. 2017, 46, 310-323.

(17) Suh, J.-M; Kim, G.; Kang, J.; Lim, M. H. Strategies employing transition metal complexes to modulate amyloid- $\beta$ aggregation. Inorg. Chem. 2019, 58, 8-17.

(18) DeToma, A. S., Salamekh, S., Ramamoorthy, A., Lim, M. H. Misfolded proteins in Alzheimer's disease and type II diabetes, Chem. Soc. Rev. 2012, 41, 608-621.

(19) Rauk, A. The chemistry of Alzheimer's disease. Chem. Soc. Rev. 2009, 38, $2698-2715$.

(20) Rajasekhar, K.; Madhu, C.; Govindaraju, T. Natural tripeptide-based inhibitor of multifaceted amyloid $\beta$ toxicity. ACS Chem. Neurosci. 2016, 7, 1300-1310. 
(21) Chen, T.; Wang, X.; He, Y.; Zhang, C.; Wu, Z.; Liao, K.; Wang, J.; Guo, Z. Effects of cyclen and cyclam on zinc(II)- and copper(II)-induced amyloid $\beta$-peptide aggregation and neurotoxicity. Inorg. Chem. 2009, 48, 5801-5809.

(22) Wu, W.; Lei, P.; Liu, Q.; Hu, J.; Gunn, A. P.; Chen, M.; Rui, Y.; Su, X.; Xie, Z.; Zhao, Y.-F; Bush, A. I.; Li, Y. Sequestration of copper from $\beta$-amyloid promotes selective lysis by cyclen-hybrid cleavage agents. J. Biol. Chem. 2008, 46, $31657-31664$.

(23) Beck, M. W.; Oh, S. B.; Kerr, R. A.; Lee, H. J.; Kim, S. H.; Kim, S.; Jang, M.; Ruotolo, B. T.; Lee, J.-Y.; Lim, M. H. A rationally designed small molecule for identifying an in vivo link between metal-amyloid- $\beta$ complexes and the pathogenesis of Alzheimer's disease. Chem. Sci. 2015, 6, 1879-1886.

(24) Hong, S.; Go, Y. K.; Derrick, J. S.; Han, S.; Kim, J.; Lim, M. H.; Kim, S. H. Advanced electron paramagnetic resonance studies of a ternary complex of copper, amyloid-b, and a chemical regulator. Inorg. Chem. 2018, 57, 1266512670.

(25) Beck, M. W.; Derrick, J. S.; Kerr, R. A.; Oh, S. B.; Cho, W. J.; Lee, S. J. C.; Ji, Y.; Han, J.; Tehrani, Z. A.; Suh, N.; Kim, S.; Larsen, S. D.; Kim, K. S.; Lee, J.-Y.; Ruotolo, B. T.; Lim, M. H. Structure-mechanism-based engineering of chemical regulators targeting distinct pathological factors in Alzheimer's disease. Nat. Commun. 2016, 7, 13115.

(26) Banks, C. E.; Lawrence, N. S.; Compton, R. G. Sonovoltammetric elucidation of electron transfer rates: the oxidation of dimethyl-p-phenylenediamine in aqueous solution. Electroanalysis 2003, 15, 243-248. 
(27) Nickel, U.; Garcia-Angel, M. G.; Ramminger, U.; Weidinger, B. Cyclic voltammetry of $\mathrm{N}, \mathrm{N}$-dimethyl-p-phenylenediamine and its $\mathrm{HCl}$-salt in acetonitrile with pyridine as proton acceptor. Z. Phys. Chem. 2006, 220, 497-509.

(28) Derrick, J. S.; Kerr, R. A.; Nam, Y.; Oh, S. B.; Lee, H. J.; Earnest, K. G.; Suh, N.; Peck, K. L.; Ozbil, M.; Korshavn, K. J.; Ramamoorthy, A.; Prabhakar, R.; Merino, E. J.; Shearer, J.; Lee, J.-Y; Ruotolo, B. T.; Lim, M. H. A redox-active, compact molecule for cross-linking amyloidogenic peptides into nontoxic, off-pathway aggregates: in vitro and in vivo efficacy and molecular mechanisms. J. Am. Chem. Soc. 2015, 137, 14785-14797.

(29) Han, J.; Lee, H. J.; Kim, K. Y.; Lee, S. J. C.; Suh, J.-M.; Cho, J.; Chae, J.; Lim, M. H. Tuning structures and properties for developing novel chemical tools toward distinct pathogenic elements in Alzheimer's disease. ACS Chem. Neurosci. 2018, 9, 800-808.

(30) Lee, J. Y.; Karlin, K. Elaboration of copper-oxygen mediated C-H activation chemistry in consideration of future fuel and feedstock generation. Curr. Opin. Chem. Biol. 2015, 25, 184-193.

(31) Himes, R. A.; Park, G. Y.; Siluvai, G. S.; Blackburn, N. J.; Karlin, K. D. Structural studies of copper(I) complexes of amyloid- $\beta$ peptide fragments: formation of twocoordinate bis(histidine) complexes. Angew. Chem. Int. Ed. 2008, 47, 90849087.

(32) Itho, S. Chemical reactivity of copper active-oxygen complexes. In Copperoxygen chemistry, Karlin, K. D.; Itho, S.; Rokita, S., Eds.; Series Ed.: S. E. Rokita; 
Wiley on Reactive intermediates in chemistry and biology, Hoboken, 2011, 5, 225-282.

(33) Davies, M. J. Protein oxidation and peroxidation. Biochem. J. 2016, 473, 805825.

(34) Cheignon, C.; Tomas, M.; Bonnefont-Rousselot, D.; Faller, P.; Hureau, C.; Collin, F. Oxidative stress and the amyloid $\beta$ peptide in Alzheimer's disease. Redox Biol. 2018, 14, 450-464.

(35) Di, L.; Kerns, E. H.; Fan, K.; McConnell, O. J.; Carter, G. T. High throughput artificial membrane permeability assay for blood-brain barrier. Eur. J. Med. Chem. 2003, 38, 223-232.

(36) Avdeef, A.; Bendels, S.; Di, L.; Faller, B.; Kansy, M.; Sugano, K.; Yamauchi, Y. PAMPA-critical factors for better predictions of absorption. J. Pharm. Sci. 2007, 96, 2893-2909.

(37) Gramec, D.; Masic, L. P.; Dolenc, M. S. Bioactivation potential of thiophenecontaining drugs. Chem. Res. Toxicol. 2014, 27, 1344-1358.

(38) Tay, S.; Le, H.; Ford, K. A.; Nelson, S. D.; Khojasteh, S. C.; Rademacher, P. M. Mechanistic studies of the cationic binding pocket of CYP2C9 in vitro and in silico: metabolism of nonionizable analogs of tienilic acid. Drug Metab. Dispos. 2014, 42, 1955-1963.

(39) Hu, Y.; Yang, S.; Shilliday, B.; Heyde, B. R.; Mandrell, K. M.; Robins, R. H.; Xie, J.; Reding, M. T.; Lai, Y.; Thompson, D. C. Novel metabolic bioactivation mechanism for a series of anti-inflammatory agents (2,5-diaminothiophene 
derivatives) mediated by cytochrome P450 enzymes. Drug. Metab. Dispos. 2010, 38, 1522-1531.

(40) Maleki, A.; Nematollahi, D. Mechanism diversity in anodic oxidation of $\mathrm{N}, \mathrm{N}-$ dimethyl-p-phenylenediamine by varing pH. J. Electroanal. Chem. 2013, 704, 75-79.

(41) Jiang, D.; Men, L.; Wang, J.; Zhang, Y.; Chickenyen, S.; Wang, Y.; Zhou, F. Redox reactions of copper complexes formed with different $\beta$-amyloid peptides and their neuropathological relevance. Biochemistry 2007, 46, 9270-9282.

(42) Choi, J.-S.; Braymer, J. J.; Nanga, R. P.; Ramamoorthy, A.; Lim, M. H. Design of small molecules that target metal-A $\beta$ species and regulate metal-induced $A \beta$ aggregation and neurotoxicity. Proc. Natl. Acad. Sci. U. S. A. 2010, 107, 2199021995.

(43) Modestov, A. D.; Gun, G.; Savotine, I.; Lev, O. On-line electrochemical-mass spectrometry study of the mechanism of oxidation of $N, N$-dimethyl-pphenylenediamine in aqueous electrolytes. J. Electroanal. Chem. 2004, 565, 719.

(44) Lee, H. J.; Korshavn, K. J.; Nam, Y.; Kang, J.; Paul, T. J.; Kerr, R. A.; Youn, I. S.; Ozbil, M.; Kim, S. S.; Ruotolo, B. T.; Prabhakar, R.; Ramamoorthy, A.; Lim, M. H. Structural and mechanistic insights into development of chemical tools to control individual and inter-related pathological features in Alzheimer's disease. Chem. Eur. J. 2017, 23, 2706-2715.

(45) Chevion, S.; Roberts, M. A.; Chevion, M. The use of cyclic voltammetry for the evaluation of antioxidant capacity. Free Radic. Biol. Med. 2000, 28, 860-870. 
(46) Ginex, T.; Trius, M.; Luque, F. J. Computational study of the Aza-Michael addition of the flavonoid $(+)$-taxifolin in the inhibition of $\beta$-amyloid fibril aggregation. Chem. Eur. J. 2018, 24, 5813-5824.

(47) Sato, M.; Murakami, K.; Uno, M.; Nakagawa, Y.; Katayama, S.; Akagi, K.; Masuda, Y.; Takegoshi, K.; Irie, K. Site-specific inhibitory mechanism for amyloid $\beta 42$ aggregation by catechol-type flavonoids targeting the Lys residues. J. Biol. Chem. 2013, 288, 23212-23224.

(48) Kang, J.; Lee, S. J. C.; Nam, J. S.; Lee, H. J.; Kang, M. G.; Korshavn, K. J.; Kim, H. T.; Cho, J.; Ramamoorthy, A.; Rhee, H.-W.; Kwon, T.-H.; Lim, M. H. An iridium(III) complex as a photoactivatable tool for oxidation of amyloidogenic peptides with subsequent modulation of peptide aggregation. Chem. Eur. J. 2017, 23, 1645-1653. 
Scheme 1. Proposed Mechanisms for Metal Binding Residue-Specific Modifications of $\mathrm{Cu}(\mathrm{II})-\mathrm{A} \beta$ by L1.

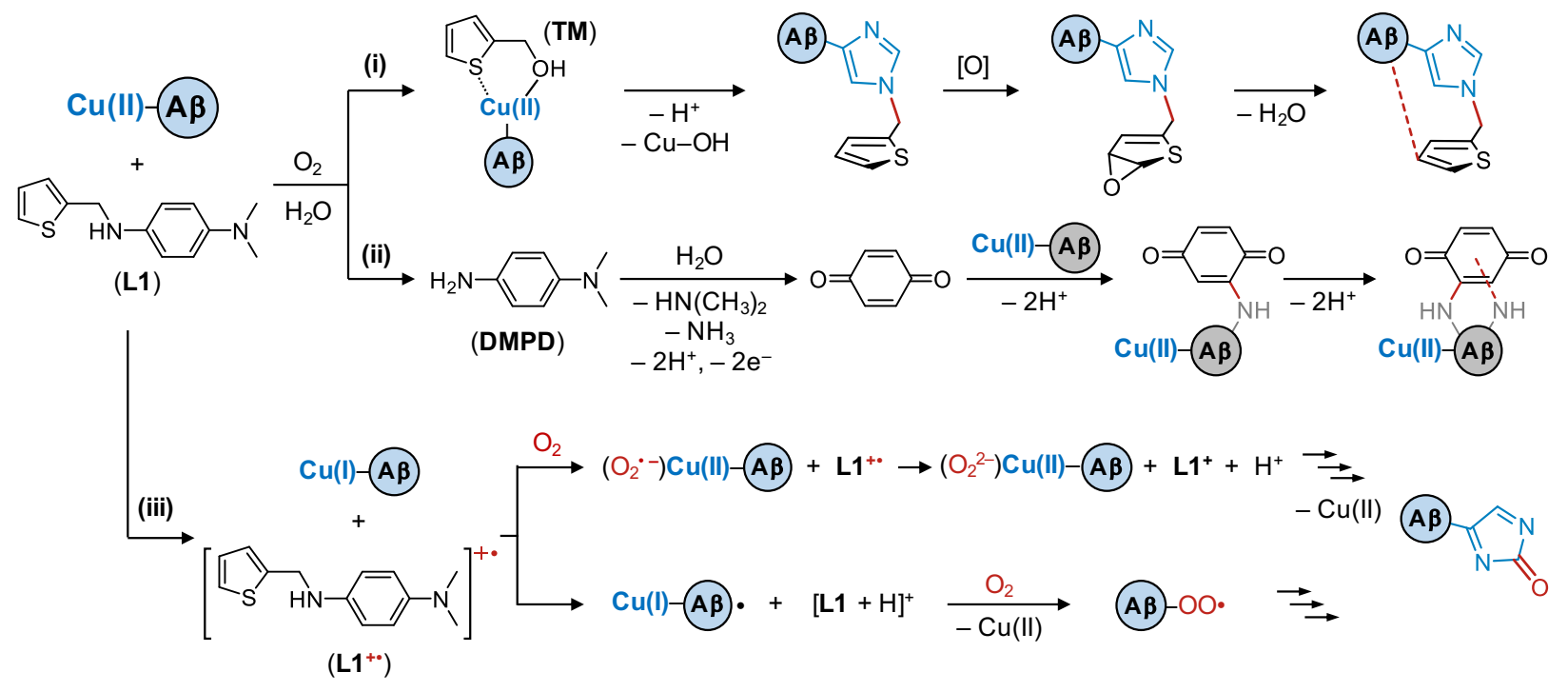


(a) Peptide modifications

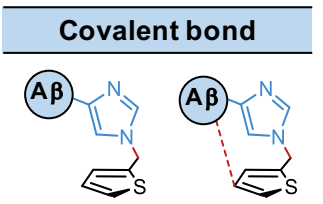

Peptide oxidation

A $\beta$

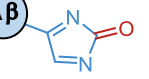

(b)

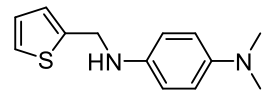

(L1)

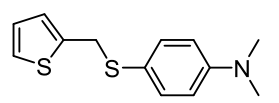

(L2)

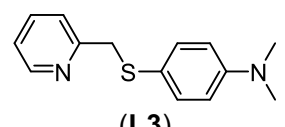

Figure 1. Peptide modifications and small molecules (L1-L3). (a) Chemical modifications (i.e., covalent adduct formation and oxidation) from the reaction of $\mathrm{Cu}(\mathrm{II})-\mathrm{A} \beta$ with a newly designed peptide modifier (L1). (b) Chemical structures of L1 $\left(N^{1}, N^{1}\right.$-dimethyl- $N^{4}$ (thiophen-2-ylmethyl)benzene-1,4-diamine), L2 $\quad(N, N$-dimethyl-4-((thiophen-2ylmethyl)thio)aniline), and L3 (N,N-dimethyl-4-((pyridin-2-ylmethyl)thio)aniline). 
(a)

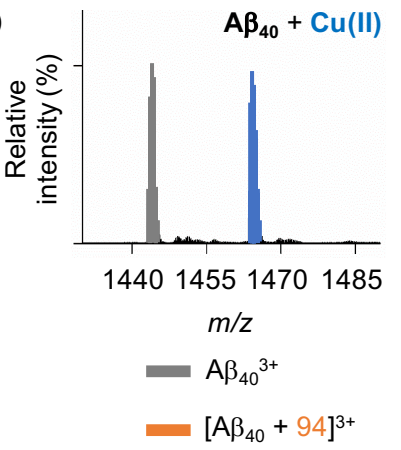

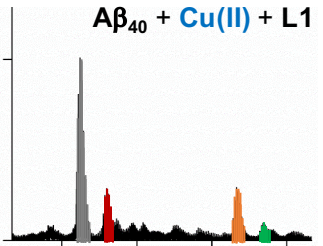

1440145514701485

$m / z$

$\left[\mathrm{A} \beta_{40}+\mathrm{Cu}(\mathrm{II})\right]^{3+}$

$\left[\mathrm{A} \beta_{40}+\mathrm{O}\right]^{3+}$ (b)

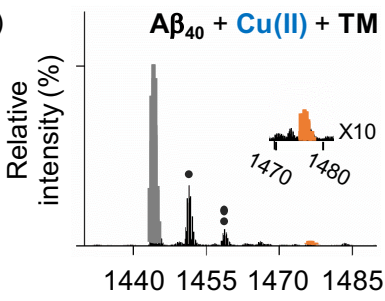

$\mathrm{m} / \mathrm{z}$

(c)

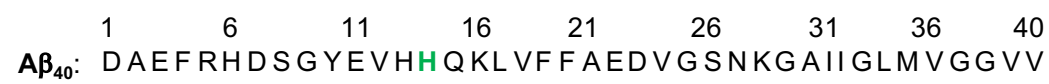

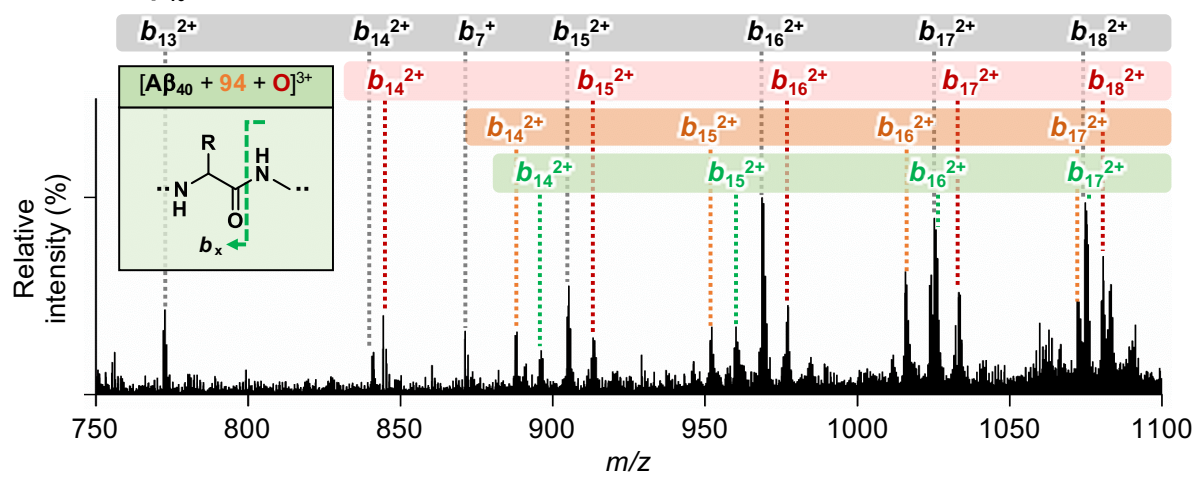

Figure 2. Modifications of $\mathrm{Cu}(\mathrm{II})$-treated $\mathrm{A} \beta_{40}$ by L1 or TM, analyzed by ESI-MS. (a and b) ESI-MS spectra of +3-charged $\mathrm{Cu}(\mathrm{II})$-treated $\mathrm{A} \beta_{40}$ monomers incubated with or without L1 or TM. The peaks of a covalent adduct between $A \beta_{40}$ and 2-methylthiophene (1476 $\mathrm{m} / \mathrm{z})$ and the singly oxidized $A \beta_{40}(1449 \mathrm{~m} / \mathrm{z})$ are indicated in orange and red, respectively. The singly oxidized covalent adduct $(1481 \mathrm{~m} / \mathrm{z})$ is presented as a green peak. One and two $\mathrm{Na}^{+}$adducts of $A \beta_{40}$ are shown with black dots. (c) ESI-MS ${ }^{2}$ spectrum of the singly oxidized covalent adduct, $\left[\mathrm{A} \beta_{40}+94+\mathrm{O}\right]^{3+}$, detected at $1481 \mathrm{~m} / \mathrm{z}$. Chemical bonds of the selected ion are cleaved by CID. The gray, red, orange, and green boxes indicate $b_{x}$ fragments corresponding to $A \beta$, oxidized $A \beta, A \beta$ bound to 2-methylthiophene, and oxidized $A \beta$ bound to 2-methylthiophene, respectively. Conditions: $\left[A \beta_{40}\right]=100 \mu \mathrm{M}$; $\left[\mathrm{CuCl}_{2}\right]=100 \mu \mathrm{M}$; [compound] $=500 \mu \mathrm{M}$; incubation for $1 \mathrm{~h} ; 20 \mathrm{mM}$ ammonium acetate, $\mathrm{pH} 7.2 ; 37^{\circ} \mathrm{C}$; no agitation. The samples were diluted with $\mathrm{dd}_{2} \mathrm{O}$ by 10 fold prior to injection to the mass spectrometer. 

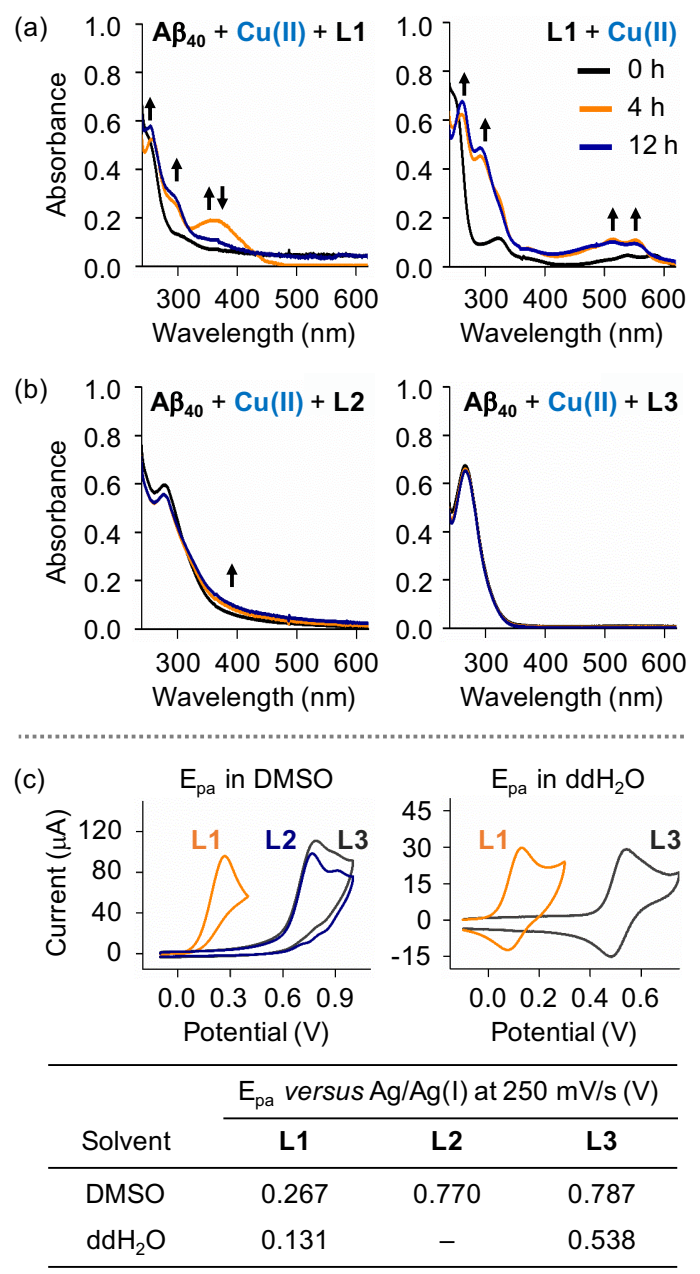

Figure 3. Transformations and oxidation potentials of L1-L3. UV-vis spectral changes of (a) L1 upon addition of $\mathrm{Cu}(\mathrm{II})$ with and without $A \beta_{40}$ and (b) L2 and L3 incubated with $\mathrm{Cu}(\mathrm{II})$ and $\mathrm{A} \beta_{40}$ under aerobic conditions. The new appearance of the peaks in (a) and (b) is indicated with black arrows. Conditions: $[\mathrm{A} \beta 40]=25 \mu \mathrm{M}$; $\left[\mathrm{CuCl}_{2}\right]=25 \mu \mathrm{M}$; [compound] $=50 \mu \mathrm{M}$; room temperature; incubation for 1 (black), 4 (red), and $12 \mathrm{~h}$ (blue). (c) Oxidation potentials ( $\mathrm{E}_{\mathrm{pa}}$ ) of $\mathbf{L 1} \mathbf{1}, \mathbf{L} 2$, and $\mathbf{L} 3$ in DMSO and $\mathrm{ddH}_{2} \mathrm{O}$, measured by cyclic voltammetry. The $E_{p a}$ values of $\mathbf{L} 1-\mathbf{L} \mathbf{3}$ at various scan rates are summarized in Tables S2 and S3. Conditions: [compound] = $1 \mathrm{mM} ; 0.1 \mathrm{M}$ tetra- $N$-butylammonium perchlorate (in DMSO) or $1 \mathrm{M} \mathrm{NaCl}$ (in $\mathrm{ddH}_{2} \mathrm{O}$ ); $250 \mathrm{mV} / \mathrm{s}$; room temperature; three electrodes are composed of the glassy carbon working electrode, platinum counter electrode, and $\mathrm{Ag} / \mathrm{Ag}(\mathrm{I})$ reference electrode. Note that the $E_{p a}$ value of $\mathbf{L 2}$ could not be measured in $\mathrm{H}_{2} \mathrm{O}$ because of its limited solubility. 


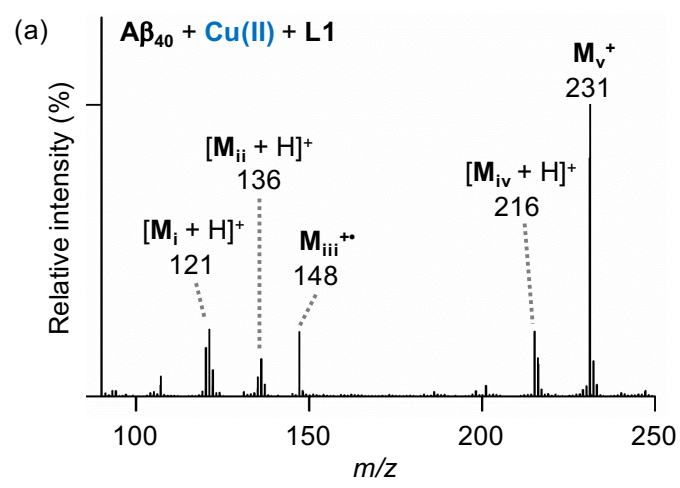

(b)
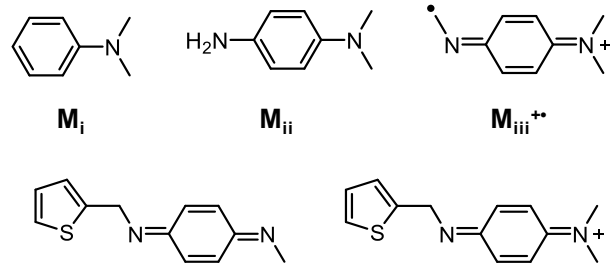

$M_{\text {iv }}$

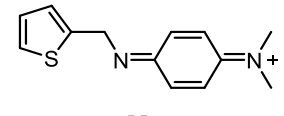

$\mathrm{M}_{\mathrm{v}}^{+}$

Figure 4. Oxidative transformations of $L 1$ upon incubation with $\mathrm{Cu}(\mathrm{II})$-treated $\mathrm{A} \beta \beta_{40}$. (a) ESI-MS spectrum from the sample containing $A \beta, C u(I I)$, and L1. (b) Chemical structures of $\mathbf{M}_{\mathbf{i}}-\mathbf{M}_{\mathbf{v}}$. Conditions: $\left[\mathrm{A} \beta_{40}\right]=100 \mu \mathrm{M} ;\left[\mathrm{CuCl}_{2}\right]=100 \mu \mathrm{M}$; [L1] = $500 \mu \mathrm{M}$; incubation for 1 h; $20 \mathrm{mM}$ ammonium acetate, $\mathrm{pH} 7.2 ; 37^{\circ} \mathrm{C}$; no agitation. The samples were diluted with $\mathrm{ddH}_{2} \mathrm{O}$ by 10 fold prior to injection to the mass spectrometer. 
(a)

A $\beta$ monomers $\pm \mathrm{Cu}(\mathrm{II}) \underset{\mathrm{N}}{\stackrel{\text { Compound }}{24 \mathrm{~h}, 37^{\circ} \mathrm{C} \text {, agitation }} \mathrm{A} \boldsymbol{\beta} \text { species }}$

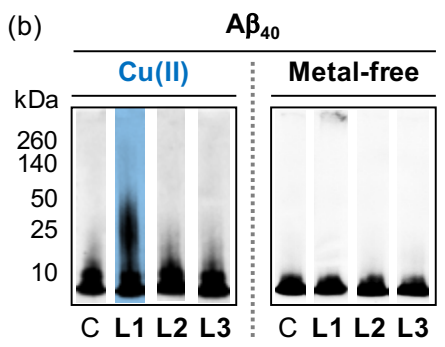

(c)
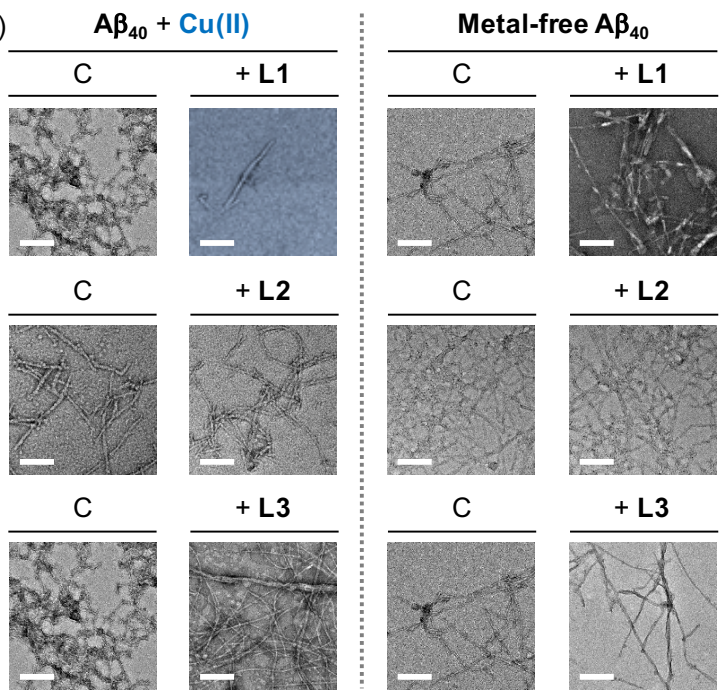

Figure 5. Analysis of $\mathrm{Cu}(\mathrm{II})$-bound and metal-free $A \beta$ aggregation with or without treatment of L1-L3. (a) Scheme of the inhibition experiments. (b) Analysis of the size distribution of the resultant $A \beta_{40}$ (top) and $A \beta_{42}$ (bottom) species by gel/Western blot using an anti-A $\beta$ antibody (6E10). Lanes: (C) A $\pm \mathrm{CuCl}_{2}$; (L1) C + L1; (L2) C + L2; (L3) C + L3. The original gel images are shown in Figure S10a. (c) Morphologies of $\mathrm{Cu}$ (II)-bound (left) and metal-free (right) $A \beta_{40}$ aggregates from (b), monitored by TEM. Scale bar $=200 \mathrm{~nm}$. Conditions: $[\mathrm{A} \beta]=25 \mu \mathrm{M} ;\left[\mathrm{CuCl}_{2}\right]=25 \mu \mathrm{M}$; [compound] $=50 \mu \mathrm{M} ; \mathrm{pH} 6.6$ [for $\mathrm{Cu}(\mathrm{II})-$ containing samples] or $\mathrm{pH} 7.4$ (for metal-free samples); $37^{\circ} \mathrm{C}$; constant agitation. 

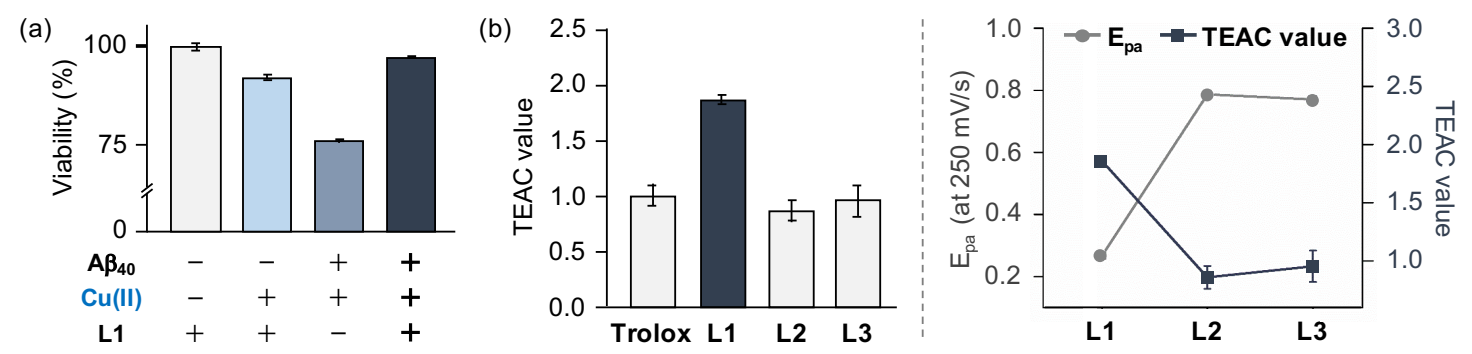

Figure 6. Regulation of $\mathrm{Cu}(\mathrm{II})-A \beta$-induced cytotoxicity and free radicals by compounds. (a) Effect of L1 on $\mathrm{Cu}(\mathrm{II})-\mathrm{A} \beta$-induced toxicity in SHSY-5Y cells, determined by the MTT assay. Cell viability was calculated in comparison to that obtained upon treatment with DMSO only $(1 \% \mathrm{v} / \mathrm{v}) . P<0.05$. Conditions: $\left[\mathrm{A} \beta_{40}\right]=10 \mu \mathrm{M},\left[\mathrm{CuCl}_{2}\right]=5 \mu \mathrm{M}$, [compound $]=$ $10 \mu \mathrm{M} ; 37^{\circ} \mathrm{C}$. (b) Scavenging capability of L1-L3 against free organic radicals (in EtOH), measured by the TEAC assay, and the plot of the TEAC values of the compounds with their $\mathrm{E}_{\mathrm{pa}}$ values. 


\title{
Supporting Information
}

\author{
for \\ Mechanistic Approaches for Modifying the Coordination Sphere of \\ Metal-Amyloid- $\beta$ Complexes: Covalent Adduct Formation and Oxidation
}

Jiyeon Han, ${ }^{\dagger}$ Hyuck Jin Lee, ${ }^{\dagger,}$ Kyu Yeon Kim, ${ }^{\ddagger}$ Junghyun Chae, ${ }^{\ddagger}$ Mi Hee Lim ${ }^{\dagger}{ }^{*}$

†Department of Chemistry, Korea Advanced Institute of Science and Technology (KAIST),

Daejeon 34141, Republic of Korea

§Department of Chemistry Education, Kongju National University, Kongju 32588,

Republic of Korea

¥Department of Chemistry, Sungshin Women’s University, Seoul 02844, Republic of Korea

*To whom correspondence should be addressed: miheelim@kaist.ac.kr 
Table of Contents

Experimental Section

Scheme S1. Synthetic routes to L1-L3

Table S1. Values (MW, $\operatorname{cog} P, \mathrm{HBA}, \mathrm{HBD}, \mathrm{PSA}, \log B \mathrm{~B}$, and $\left.-\log P_{\mathrm{e}}\right)$ of L1-L3 S10

Table S2. Quantitative data of cyclic voltammograms of compounds in DMSO S11

Table S3. Quantitative data of cyclic voltammograms of compounds in $\mathrm{ddH}_{2} \mathrm{O} \mathrm{S} 12$

Figure S1. $\quad{ }^{1} \mathrm{H}$ and ${ }^{13} \mathrm{C}$ NMR spectra of L1

Figure S2. $\quad{ }^{1} \mathrm{H}$ and ${ }^{13} \mathrm{C}$ NMR spectra of L2 $\quad \mathrm{S} 14$

Figure S3. $\quad{ }^{1} \mathrm{H}$ and ${ }^{13} \mathrm{C}$ NMR spectra of L3 $\quad$ S15

Figure S4. Interactions of $\mathbf{L 2}$ and $\mathbf{L} 3$ with $\mathrm{Cu}(\mathrm{II})$-treated $\mathrm{A} \beta_{40} \quad \mathrm{~S} 16$

$\begin{array}{lll}\text { Figure S5. Interactions of L1-L3 with metal-free } A \beta_{40} & \text { S17 }\end{array}$

Figure S6. Transformations of L1-L3 in the presence of $\mathrm{Cu}(\mathrm{II}) \quad$ S18

Figure S7. Oxidation potentials of L1-L3 in DMSO $\quad$ S19

Figure S8. Oxidation potentials of $\mathbf{L} 1$ and $\mathbf{L} 3$ in $\mathbf{d d H}_{2} \mathrm{O} \quad \mathbf{S} 20$

Figure S9. Impact of L1-L3 on preformed $\mathrm{Cu}(\mathrm{II})$-bound and metal-free $A \beta$ aggregates $\quad S 21$

Figure S10. Original gel images from the inhibition and disaggregation experiments

Figure S11. TEM images of the resultant $A \beta_{42}$ aggregates from the inhibition experiments

Figure S12. TEM images of the resultant $A \beta_{42}$ aggregates from the disaggregation experiments $\quad$ S24

Figure S13. Toxicity of L1-L3 in SH-SY5Y cells $\quad$ S25 


\section{Experimental Section}

\section{Materials and Methods}

All reagents were purchased from commercial suppliers and used as received unless otherwise noted. $A \beta_{40}$ and $A \beta_{42}\left(A \beta_{42}=\right.$ DAEFRHDSGYEVHHQKLVFFAEDVGSNKGAIIGLMVGGVVIA) were purchased from Anaspec (Fremont, CA, USA). Trace metal ions were removed from the solutions used for the studies by treatment with Chelex overnight (Sigma-Aldrich, St. Louis, MO, USA). ESI-MS and ESI-MS ${ }^{2}$ analyses were performed by a Waters Synapt G2-Si quadrupole time-of-flight (Q-Tof) ion mobility mass spectrometer (Waters, Manchester, UK) equipped with an ESI source [DGIST Center for Core Research Facilities (CCRF), Daegu, Republic of Korea]. Optical spectra were recorded on an Agilent 8453 UV-vis spectrophotometer. Cyclic voltammograms were obtained under $\mathrm{N}_{2}$ (g) on a CHI620E potentiostat (Qrins, Seoul, Republic of Korea). TEM images were taken by a JEOL JEM-2100 transmission electron microscope [UNIST Central Research Facilities (UCRF), Ulsan, Republic of Korea]. Absorbance values for the PAMPA-BBB measurements, the MTT assay and the Trolox equivalent antioxidant capacity (TEAC) assay [MTT $=3$-(4,5-dimethylthiazol-2-yl)-2,5-diphenyltetrazolium bromide] were obtained by a Molecular Devices SpectraMax M5e microplate reader (Sunnyvale, CA, USA). ${ }^{1} \mathrm{H}$ and ${ }^{13} \mathrm{C}$ NMR spectra were recorded on a $400 \mathrm{MHz}$ Agil ent NMR spectrometer (UCRF). The high-resolution mass spectra of compounds were taken by a $Q$ exactive plus orbitrap mass spectrometer (Thermo Fisher Scientific, Carlsbad, CA, USA).

Preparation of L1. 2-Thiophenecarboxaldehyde $(0.098 \mathrm{~mL}, 1 \mathrm{mmol})$ was added into a solution of $N, N$-dimethyl-p-phenylenediamine $(140 \mathrm{mg}, 1 \mathrm{mmol})$ in $\mathrm{EtOH}(5 \mathrm{~mL})$. After refluxing the solution for $1 \mathrm{~h}$, the reaction mixture was cooled to room temperature. The solvent was removed under vacuum yielding an imine product (brown solid). Sodium borohydride $\left(\mathrm{NaBH}_{4} ; 230 \mathrm{mg}, 6 \mathrm{mmol}\right)$ was added into a solution of the imine product (230 mg, $1 \mathrm{mmol}$ ) in $\mathrm{CH}_{3} \mathrm{OH}(10 \mathrm{~mL})$ at $0{ }^{\circ} \mathrm{C}$. After $10 \mathrm{~min}$, the reaction mixture was stirred at room temperature for $30 \mathrm{~min}$. The reaction was quenched with $\mathrm{H}_{2} \mathrm{O}$ and extracted with $\mathrm{CH}_{2} \mathrm{Cl}_{2}(3 \mathrm{x})$. The combined organic phase was washed with brine (1x) and dried over anhydrous magnesium sulfate $\left(\mathrm{MgSO}_{4}\right)$. The crude compound was purified by column 
chromatography $\left(\mathrm{SiO}_{2}\right.$; EtOAc:hexanes $\left.=1: 3\right)$ yielding a yellow solid product $(130 \mathrm{mg}$, 54\%). ${ }^{1} \mathrm{H}$ NMR [400 MHz, DMSO-d6, $\left.\delta(\mathrm{ppm})\right]: 7.33(1 \mathrm{H}, \mathrm{dd}, J=1.2 \mathrm{~Hz}, J=5.0 \mathrm{~Hz}), 7.01$ $(1 \mathrm{H}, \mathrm{dq}, J=3.6 \mathrm{~Hz}), 6.95(1 \mathrm{H}, \mathrm{dd}, J=3.6 \mathrm{~Hz}, \mathrm{~J}=5.0 \mathrm{~Hz}), 6.62-6.59(2 \mathrm{H}, \mathrm{m}), 6.58-6.54$ $(2 \mathrm{H}, \mathrm{m}), 5.60-5.57(1 \mathrm{H}, \mathrm{m}), 4.36(2 \mathrm{H}, \mathrm{d}, J=5.6 \mathrm{~Hz}), 2.70(6 \mathrm{H}, \mathrm{s}) .{ }^{13} \mathrm{C}$ NMR [100 MHz, DMSO- $\left.d_{6}, \delta(\mathrm{ppm})\right]: 145.1,143.2,140.5,126.6,124.4,124.2,115.1,113.8,43.0,41.7$. HRMS $(\mathrm{m} / \mathrm{z}):[\mathrm{M}+\mathrm{H}]^{+}$Calcd. for $\mathrm{C}_{13} \mathrm{H}_{17} \mathrm{~N}_{2} \mathrm{~S}$ : 233.1112, found: 233.1099 .

Preparation of L2. 2-(Bromomethyl)thiophene $(62 \mathrm{mg}, 0.4 \mathrm{mmol})$ was added dropwise to a solution of potassium hydroxide $(\mathrm{KOH} ; 33 \mathrm{mg}, 0.6 \mathrm{mmol})$ and 4(dimethylamino)benzenethiol (30 mg, $0.2 \mathrm{mmol}$ ) in $\mathrm{DMF} / \mathrm{H}_{2} \mathrm{O}(2 \mathrm{~mL} / 0.2 \mathrm{~mL})$. The reaction mixture was stirred at room temperature for $24 \mathrm{~h}$ and then cooled to $0{ }^{\circ} \mathrm{C}$. The reaction was quenched with $\mathrm{H}_{2} \mathrm{O}$ and extracted with EtOAc (4x). The combined organic layer was dried over anhydrous $\mathrm{MgSO}_{4}$ and concentrated under vacuum. The crude compound was purified by column chromatography $\left(\mathrm{SiO}_{2}\right.$; EtOAc:hexanes $\left.=1: 6\right)$ yielding a yellow liquid product (36 mg, 73\%). ${ }^{1} \mathrm{H}$ NMR [400 MHz, DMSO- $\left.d_{6}, \delta(\mathrm{ppm})\right]: 7.36(1 \mathrm{H}, \mathrm{dd}, J=5.1 \mathrm{~Hz}$, $J=1.3 \mathrm{~Hz}), 7.22-7.18(2 \mathrm{H}, \mathrm{m}), 6.88(1 \mathrm{H}, \mathrm{dd}, J=5.1 \mathrm{~Hz}, J=3.4 \mathrm{~Hz}), 6.82-6.81(1 \mathrm{H}, \mathrm{m})$, 6.66-6.62 (2H, m), $4.21(2 \mathrm{H}, \mathrm{d}, J=0.7 \mathrm{~Hz}), 2.80(6 \mathrm{H}, \mathrm{s}) .{ }^{13} \mathrm{C} \mathrm{NMR}\left[100 \mathrm{MHz}, \mathrm{CD}_{3} \mathrm{OD}, \delta\right.$ (ppm)]: 150.5, 141.8, 134.4, 126.0, 125.7, 124.1, 120.1, 112.3, 39.2, 35.5. HRMS (m/z): $[\mathrm{M}+\mathrm{H}]^{+}$Calcd. for $\mathrm{C}_{13} \mathrm{H}_{16} \mathrm{NS}_{2}: 250.0724$, found: 250.0713 .

Preparation of L3. 2-(Bromomethyl)pyridine hydrobromide (100 $\mathrm{mg}, 0.4 \mathrm{mmol}$ ) was added dropwise to a mixture of $\mathrm{KOH}(57 \mathrm{mg}, 1 \mathrm{mmol}$ ) and 4-(dimethylamino)benzenethiol (30 mg, $0.2 \mathrm{mmol})$ in $\mathrm{DMF} / \mathrm{H}_{2} \mathrm{O}(3 \mathrm{~mL} / 0.3 \mathrm{~mL})$. The reaction mixture was stirred for $4 \mathrm{~h}$ at room temperature and then cooled to $0{ }^{\circ} \mathrm{C}$. The mixture was diluted with $\mathrm{H}_{2} \mathrm{O}$ and extracted with EtOAc (4x). The combined organic layer was dried over anhydrous $\mathrm{MgSO}_{4}$ and concentrated under vacuum. The crude compound was purified by column chromatography $\left(\mathrm{SiO}_{2}\right.$; EtOAc:hexanes $\left.=1: 4\right)$ yielding a yellow liquid product $(33 \mathrm{mg}$, 65\%). ${ }^{1} \mathrm{H}$ NMR [400 MHz, $\left.\mathrm{CD}_{3} \mathrm{OD}, \delta(\mathrm{ppm})\right]: 8.40(1 \mathrm{H}, \mathrm{ddd}, J=0.8 \mathrm{~Hz}, J=4.8 \mathrm{~Hz}), 7.67$ $(1 \mathrm{H}, \mathrm{td}, J=7.6 \mathrm{~Hz}, J=1.6 \mathrm{~Hz}), 7.25(1 \mathrm{H}, \mathrm{ddd}, J=1.2 \mathrm{~Hz}), 7.22-7.14(3 \mathrm{H}, \mathrm{m}), 6.64-6.60$ $(2 \mathrm{H}, \mathrm{m}), 4.01(2 \mathrm{H}, \mathrm{s}), 2.90(6 \mathrm{H}, \mathrm{s}) .{ }^{13} \mathrm{C}$ NMR [100 MHz, $\left.\mathrm{CD}_{3} \mathrm{OD}, \delta(\mathrm{ppm})\right]:$ 159.8, 152.0, 
149.5, 138.4 136.0, 125.2, 123.4, 120.6, 113.9, 43.6, 40.6. HRMS (m/z): [M + H] Calcd. for $\mathrm{C}_{14} \mathrm{H}_{17} \mathrm{~N}_{2} \mathrm{~S}: 245.1112$, found: 245.1099 .

\section{Parallel Artificial Membrane Permeability Assay Adapted for the Blood-Brain} Barrier (PAMPA-BBB). PAMPA-BBB experiments were conducted employing the PAMPA Explorer kit ( $p I O N$ Inc., Billerica, MA, USA) following previously reported protocols. ${ }^{1-3}$ Compounds $(25 \mu \mathrm{M}, 200 \mu \mathrm{L})$ in Prisma HT buffer $(\mathrm{pH} 7.4, p \mathrm{ION})$ were added to the wells of a donor plate (number of replicates $=12$ ). The polyvinylidene fluoride (PVDF, $0.45 \mu \mathrm{M})$ filter membrane on the acceptor plate was coated with BBB-1 lipid formulation $(5 \mu \mathrm{L}, p I O N)$. The acceptor plate was then placed on the top of the donor plate. Brain sink buffer (BSB, $200 \mu \mathrm{L}, p I O N)$ was added to each well of the acceptor plate and was incubated for $4 \mathrm{~h}$ at room temperature without agitation. UV-vis spectra of the solutions in the reference, acceptor, and donor plates were measured by a microplate reader. The PAMPA Explorer software v. $3.5(\mathrm{plON})$ was used to calculate the $-\log P_{\mathrm{e}}$ values for compounds. CNS \pm designations were assigned by comparison with compounds that were identified in the previous reports. ${ }^{4,5}$

A $\beta$ Aggregation Experiments. $A \beta_{40}$ or $A \beta_{42}$ was dissolved in ammonium hydroxide $\left[\mathrm{NH}_{4} \mathrm{OH}(\mathrm{aq}) ; 1 \% \mathrm{v} / \mathrm{v}\right]$. The resulting solution was lyophilized and stored at $-80^{\circ} \mathrm{C}$. A stock solution of $A \beta$ was then prepared by dissolving the lyophilized peptide with $\mathrm{NH}_{4} \mathrm{OH}(1 \%$ $v / v, 10 \mu \mathrm{L}$ ) and diluting with $d \mathrm{dH}_{2} \mathrm{O}$. All $\mathrm{A} \beta$ samples were prepared following the previously reported procedures. ${ }^{1-3,6}$ The concentration of the peptide solution was determined by measuring the absorbance of the solution at $280 \mathrm{~nm}\left(\varepsilon=1,450 \mathrm{M}^{-1} \mathrm{~cm}^{-1}\right.$ for $A \beta_{40} ; \varepsilon=$ $1,490 \mathrm{M}^{-1} \mathrm{~cm}^{-1}$ for $\left.A \beta_{42}\right)$. The peptide stock solution was diluted to a final concentration of $25 \mu \mathrm{M}$ in the Chelex-treated buffer [20 $\mu \mathrm{M}$ HEPES, pH 6.6 [for $\mathrm{Cu}(\mathrm{II})$ samples] or $\mathrm{pH} 7.4$ (for metal-free samples), $150 \mu \mathrm{M} \mathrm{NaCl}$. For the inhibition studies, compounds (final concentration, $50 \mu \mathrm{M} ; 1 \% \mathrm{v} / \mathrm{v}$ DMSO) were added to the samples of $\mathrm{A} \beta(25 \mu \mathrm{M})$ in the absence and presence of a copper chloride salt $\left(\mathrm{CuCl}_{2} ; 25 \mu \mathrm{M}\right)$ followed by incubation at $37^{\circ} \mathrm{C}$ with constant agitation for $24 \mathrm{~h}$. For the disaggregation studies, $\mathrm{A} \beta(25 \mu \mathrm{M})$ was incubated with and without $\mathrm{CuCl}_{2}(25 \mu \mathrm{M})$ for $24 \mathrm{~h}$ at $37{ }^{\circ} \mathrm{C}$ with constant agitation to 
generate preformed $A \beta$ aggregates. The resulting peptide aggregates were then treated with compounds $(50 \mu \mathrm{M})$ and incubated with constant agitation for an additional $24 \mathrm{~h}$.

Electrospray lonization-Mass Spectrometry (ESI-MS) and Tandem MS (ESI-MS²). The experiments were performed following the previously reported methods. ${ }^{7-9} A \beta_{40}$ (100 $\mu \mathrm{M})$ was incubated with compounds (500 $\mu \mathrm{M} ; 1 \% \mathrm{v} / \mathrm{v}$ DMSO) and/or $\mathrm{CuCl}_{2}(100 \mu \mathrm{M})$ in $20 \mathrm{mM}$ ammonium acetate $\left(\mathrm{pH} \mathrm{7.2)}\right.$ at $37^{\circ} \mathrm{C}$ without agitation. Incubated samples were diluted by 10 fold with $\mathrm{ddH}_{2} \mathrm{O}$ and then injected into the mass spectrometer. The capillary voltage, sampling cone voltage, and source temperature were set to $2.8 \mathrm{kV}, 70 \mathrm{~V}$, and $40{ }^{\circ} \mathrm{C}$, respectively. The backing pressure was adjusted to $2.7 \mathrm{mbar}$. Tandem MS (ESI$\mathrm{MS}^{2}$ ) analyses were additionally performed on the $\mathrm{TM}-\mathrm{Cu}(\mathrm{II})-\mathrm{A} \beta$ complexes. The ESI parameters and experimental conditions were the same as above. The collision-induced dissociation (CID) was conducted by applying the collision energy in the trap and adjusting the low mass (LM) resolution to 15 . More than 200 spectra were obtained for each sample and averaged for the analysis.

Cyclic Voltammetry. Cyclic voltammograms of compounds (dissolved in DMSO; final concentration, $1 \mathrm{mM}$ ) were recorded in $0.1 \mathrm{M}$ tetra- $N$-butylammonium perchlorate (in DMSO) and $1 \mathrm{M} \mathrm{NaCl}$ (in $\mathrm{ddH}_{2} \mathrm{O} ; 1 \% \mathrm{v} / \mathrm{v}$ DMSO) at various scan rates $(25,50,100,150$, 200 , and $250 \mathrm{mV} / \mathrm{s}$ ) at room temperature. A three-electrode setup is composed of an $\mathrm{Ag} / \mathrm{Ag}(\mathrm{I})$ reference electrode [RE-1B Reference electrode $\mathrm{Ag} / \mathrm{Ag}(\mathrm{I})$; Qrins], a Pt wire auxiliary electrode (SPTE Platinum electrode; Qrins), and a glassy carbon working electrode (Qrins).

Gel Electrophoresis with Western Blot (Gel/Western Blot). The resultant A $\beta$ species from in vitro experiments were analyzed by gel/Western blot using an anti-A $\beta$ antibody (6E10). ${ }^{1-3,6}$ The samples $(10 \mu \mathrm{L})$ were separated on a $10-20 \%$ Tris-tricine gel (Thermo Fisher Scientific). Following separation, the proteins were transferred onto nitrocellulose membranes and blocked with bovine serum albumin (BSA, 3\% w/v, Sigma-Aldrich) in Tris-buffered saline (TBS) containing $0.1 \%$ Tween-20 (TBS-T) for $2 \mathrm{~h}$ (at room 
temperature) or overnight (at $4{ }^{\circ} \mathrm{C}$ ). The membranes were incubated with the anti-A $\beta$ antibody (6E10) $(1: 2,000$, Covance, Princeton, NJ, USA) in a solution of BSA ( $2 \% \mathrm{w} / \mathrm{v}$ in TBS-T) for $4 \mathrm{~h}$ (at room temperature) or overnight (at $4{ }^{\circ} \mathrm{C}$ ). After washing with TBS-T ( $3 \mathrm{x}$, $10 \mathrm{~min}$ ), a horseradish peroxidase-conjugated goat anti-mouse secondary antibody (1:5,000 in 2\% w/v BSA in TBS-T; Cayman Chemical Company, MI, USA) was added for $1.5 \mathrm{~h}$ at room temperature. $A$ homemade $E C L$ kit $^{7,8,10}$ was used to visualize the gel/Western blots on a ChemiDoc MP Imaging System (Bio-Rad, Hercules, CA, USA).

Transmission Electron Microscopy (TEM). Samples for TEM were prepared following the previously reported methods. ${ }^{1-3,6-8}$ Glow-discharged grids (Formvar/Carbon 300mesh, Electron Microscopy Sciences, Hatfield, PA, USA) were treated with A $\beta$ samples $(25 \mu \mathrm{M}, 5 \mu \mathrm{L})$ for $2 \mathrm{~min}$ at room temperature. Excess sample was removed using filter paper followed by washing twice with $\mathrm{dd}_{2} \mathrm{O}$. Each grid, incubated with uranyl acetate $\left(1 \%, d_{d} \mathrm{H}_{2} \mathrm{O}, 5 \mu \mathrm{L}\right)$ for $1 \mathrm{~min}$, was blotted off and dried for $15 \mathrm{~min}$ at room temperature. Images for each sample were taken with $200 \mathrm{kV}$ and 25,000x magnification.

Cell Viability Studies. The human neuroblastoma SH-SY5Y cell line was purchased from the American Type Culture Collection (ATCC, VA, USA). The cell line was maintained in media containing 50\% minimum essential medium (MEM) and 50\% F12 (GIBCO, NY, USA), and supplemented with 10\% fetal bovine serum (Sigma-Aldrich), 100 $\mathrm{U} / \mathrm{mL}$ penicillin, and $100 \mathrm{mg} / \mathrm{mL}$ streptomycin (GIBCO). Cells were grown and maintained at $37{ }^{\circ} \mathrm{C}$ in a humidified atmosphere with $5 \% \mathrm{CO}_{2}$. The cells used for our studies did not indicate mycoplasma contamination. Cell viability upon treatment with compounds was determined by the MTT assay. Cells were seeded in a 96 well plate $(15,000$ cells in 100 $\mu \mathrm{L}$ per well) and treated with compounds (5, 10, and $25 \mu \mathrm{M}, 1 \% \mathrm{v} / \mathrm{v}$ DMSO). After $24 \mathrm{~h}$ incubation, MTT [25 $\mu \mathrm{L}$ of $5 \mathrm{mg} / \mathrm{mL}$ in PBS ( $\mathrm{pH} 7.4$, GIBCO)] was added to each well, and the plate was incubated for $4 \mathrm{~h}$ at $37^{\circ} \mathrm{C}$. Formazan produced by cells was solubilized using an acidic solution of DMF ( $\mathrm{pH} 4.5,50 \% \mathrm{v} / \mathrm{v}$, aq) and sodium dodecyl sulfate (SDS; $20 \% \mathrm{w} / \mathrm{v}$ ) overnight at room temperature in the dark. The absorbance was measured at 
$600 \mathrm{~nm}$ by a microplate reader. Cell viability was calculated relative to that of the cells containing an equivalent amount of DMSO.

Trolox equivalent antioxidant capacity (TEAC) Assay. The ability of compounds to scavenge free organic radicals in $\mathrm{EtOH}$ was determined by the assay according to a previously reported method with slight modifications. ${ }^{1,7}$ To generate blue ABTS cation radicals $\left[\mathrm{ABTS}^{+*} ; \mathrm{ABTS}=2,2^{\prime}\right.$-azino-bis(3- ethylbenzothiazoline-6-sulfonic acid) diammonium salt; Sigma], ABTS $\left(7.0 \mathrm{mM}\right.$, Sigma) with potassium persulfate $\left[\mathrm{K}_{2}\left(\mathrm{SO}_{4}\right)_{2}\right.$; $2.5 \mathrm{mM}$ ] was dissolved in $5 \mathrm{~mL}$ of $\mathrm{ddH}_{2} \mathrm{O}$ and incubated for $16 \mathrm{~h}$ in the dark at room temperature. The resulting solution of $\mathrm{ABTS}^{+\cdot}$ was diluted with $\mathrm{EtOH}$ to absorbance of $c a$. 0.7 at $734 \mathrm{~nm}$. The solution of $\mathrm{ABTS}^{+\bullet}(200 \mu \mathrm{L})$ was added to the wells of a clear 96 well plate. Our compounds and Trolox (Trolox $=6$-hydroxy-2,5,7,8-tetramethyl-chroman-2carboxylic acid) were dissolved in $\mathrm{EtOH}$ and treated to the solution of ABTS ${ }^{+\cdot}$. The final concentrations $(2.1,4.3,6.4,8.6,11$, and $16 \mu \mathrm{M})$ of compounds and Trolox were used. After $10 \mathrm{~min}$ incubation at room temperature, the absorbance at $750 \mathrm{~nm}$ was recorded. The percent inhibition was calculated according to the measured absorbance [\% inhibition $=100 \times\left(A_{0}-A\right) / A_{0}$, where $A$ and $A_{0}$ are the absorbance of the samples with and without compound treatment, respectively] and was plotted as a function of compound concentration. The TEAC values of compounds for each time point were calculated as a ratio of the slope of the compound to that of Trolox. 
Scheme S1. Synthetic routes to L1-L3.

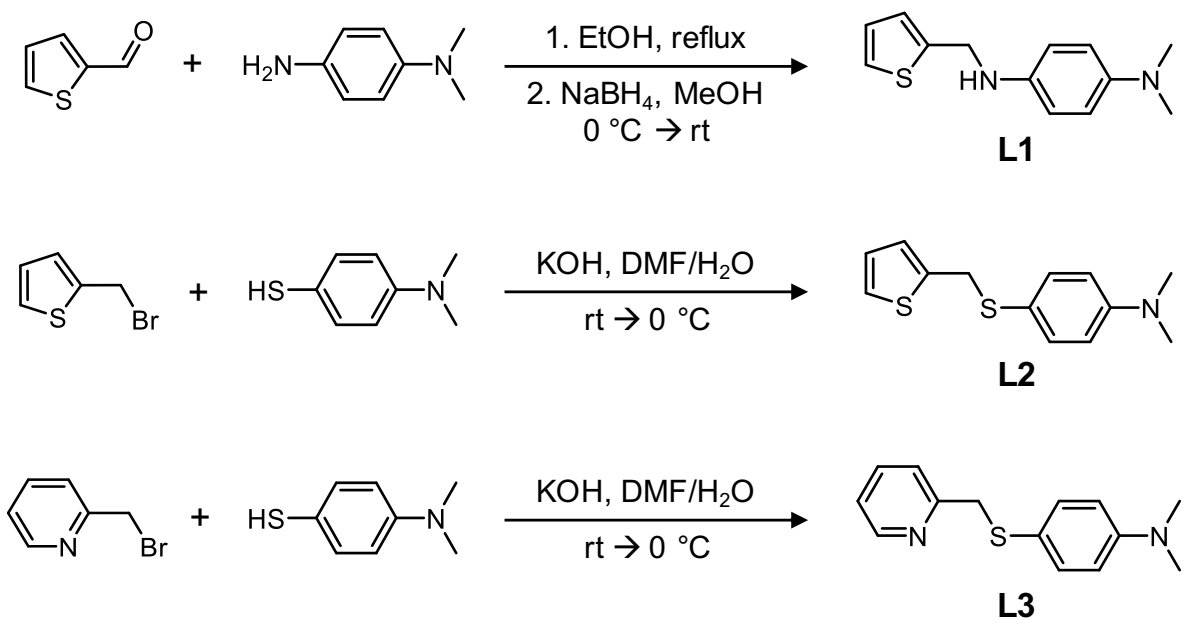


Table S1. Values (MW, $\operatorname{cog} P, \mathrm{HBA}, \mathrm{HBD}, \mathrm{PSA}, \operatorname{logBB}$, and $\left.-\log P_{\mathrm{e}}\right)$ of L1-L3.

\begin{tabular}{ccccc}
\hline & L1 & L2 & L3 & Lipinski's rules and others \\
\hline $\mathrm{MW}^{a}$ & 232 & 249 & 244 & $\leq 450$ \\
$\mathrm{Clog} P^{b}$ & 15.3 & 4.08 & 2.94 & $\leq 5$ \\
$\mathrm{HBA}^{c}$ & 2 & 1 & 2 & $\leq 10$ \\
$\mathrm{HBD}^{d}$ & 1 & 0 & 0 & $\leq 5$ \\
$\mathrm{PSA}\left(\AA^{2}\right)^{e}$ & 15.3 & 3.24 & 16.1 & $\leq 90$ \\
$\operatorname{logBB}$ & 0.345 & 0.702 & 0.338 & $<-1.0($ poorly) \\
& $4.31 \pm 0.13$ & $4.61 \pm 0.22$ & $4.35 \pm 0.07$ & $-\log P_{\mathrm{e}}<5.4(\mathrm{CNS}+)$ \\
$-\log P_{\mathrm{e}}{ }^{g}$ & $(\mathrm{CNS}+)$ & $(\mathrm{CNS}+)$ & $(\mathrm{CNS}+)$ & $-\log P_{\mathrm{e}}>5.7(\mathrm{CNS}-)$ \\
\hline
\end{tabular}

${ }^{a} \mathrm{MW}$, molecular weight; ${ }^{b} \mathrm{clog} P$, calculated log of water-octanol partition coefficient; ${ }^{\mathrm{CHBA}}$, hydrogen bond acceptor atom; ${ }^{d} \mathrm{HBD}$, hydrogen bond donor atom; ${ }^{\mathrm{P} S A}$, polar surface area; ${ }^{\prime} \log B B=0.152 \times c \log P-0.0148 \times P S A+0.139 ;{ }^{g}-\log P_{e}$, the value obtained using the PAMPA-BBB assay with the PAMPA Explorer software v. 3.5. Compounds assigned to be CNS+ are able to penetrate the BBB and thus be available in the central nervous system (CNS). 
Table S2. Quantitative data of cyclic voltammograms of compounds in DMSO.

\begin{tabular}{|c|c|c|c|c|c|c|}
\hline \multirow{2}{*}{$\begin{array}{c}\text { Scan rate } \\
(\mathrm{mV} / \mathrm{s})\end{array}$} & \multicolumn{2}{|c|}{ L1 } & \multicolumn{2}{|c|}{ L2 } & \multicolumn{2}{|c|}{ L3 } \\
\hline & $\mathrm{E}_{\mathrm{pa}}(\mathrm{V})$ & $\mathrm{i}_{\mathrm{pa}}(\mu \mathrm{A})$ & $E_{p a}(V)$ & $\mathrm{i}_{\mathrm{pa}}(\mu \mathrm{A})$ & $E_{p a}(V)$ & $\mathrm{i}_{\mathrm{pa}}(\mu \mathrm{A})$ \\
\hline 25 & 0.209 & 7.22 & 0.716 & 18.6 & 0.730 & 22.5 \\
\hline 50 & 0.225 & 14.0 & 0.732 & 25.6 & 0.748 & 31.9 \\
\hline 100 & 0.241 & 18.9 & 0.749 & 39.1 & 0.763 & 44.6 \\
\hline 150 & 0.251 & 20.0 & 0.756 & 48.4 & 0.770 & 49.4 \\
\hline 200 & 0.256 & 26.4 & 0.761 & 48.7 & 0.775 & 56.7 \\
\hline 250 & 0.267 & 41.9 & 0.770 & 53.3 & 0.787 & 60.5 \\
\hline
\end{tabular}


Table S3. Quantitative data of cyclic voltammograms of compounds in $\mathrm{ddH}_{2} \mathrm{O}$. ${ }^{a}$

\begin{tabular}{ccccc}
\hline \multirow{2}{*}{$\begin{array}{c}\text { Scan rate } \\
(\mathrm{mV} / \mathrm{s})\end{array}$} & \multicolumn{4}{c}{$\mathrm{L1}$} \\
\cline { 2 - 5 } & $\mathrm{E}_{\mathrm{pa}}(\mathrm{V})$ & $\mathrm{i}_{\mathrm{pa}}(\mu \mathrm{A})$ & $\mathrm{E}_{\mathrm{pc}}(\mathrm{V})$ & $\mathrm{i}_{\mathrm{pc}}(\mu \mathrm{A})$ \\
\hline 25 & 0.117 & 2.58 & 0.0721 & 0.106 \\
50 & 0.116 & 3.96 & 0.0764 & 0.341 \\
100 & 0.118 & 5.73 & 0.0798 & 0.373 \\
150 & 0.122 & 9.33 & 0.0734 & 0.993 \\
200 & 0.129 & 12.2 & 0.0793 & 1.61 \\
250 & 0.131 & 15.2 & 0.0812 & 1.57 \\
\hline \hline Scan rate & \multicolumn{4}{c}{$\mathrm{L3}$} \\
$(\mathrm{mV} / \mathrm{s})$ & $\mathrm{E}_{\mathrm{pa}}(\mathrm{V})$ & $\mathrm{i}_{\mathrm{pa}}(\mu \mathrm{A})$ & $\mathrm{E}_{\mathrm{pc}}(\mathrm{V})$ & $\mathrm{i}_{\mathrm{pc}}(\mu \mathrm{A})$ \\
\hline 25 & 0.544 & 4.92 & 0.481 & 2.72 \\
50 & 0.539 & 7.01 & 0.481 & 4.21 \\
100 & 0.536 & 11.0 & 0.483 & 6.30 \\
150 & 0.538 & 13.3 & 0.483 & 7.75 \\
200 & 0.539 & 16.3 & 0.483 & 9.52 \\
250 & 0.538 & 21.0 & 0.48 & 11.0 \\
\hline
\end{tabular}

${ }^{a}$ Note that the $\mathrm{E}_{\mathrm{pa}}$ of $\mathbf{L 2}$ could not be measured in $1 \mathrm{M} \mathrm{NaCl}$ due to its limited solubility in $\mathrm{H}_{2} \mathrm{O}$. 
(a)

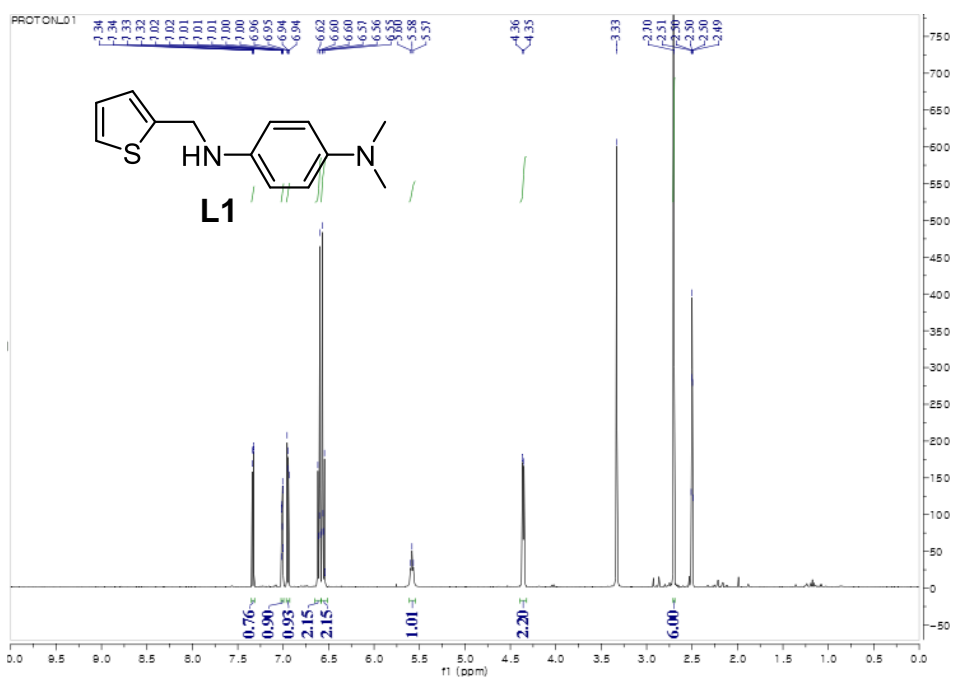

(b)

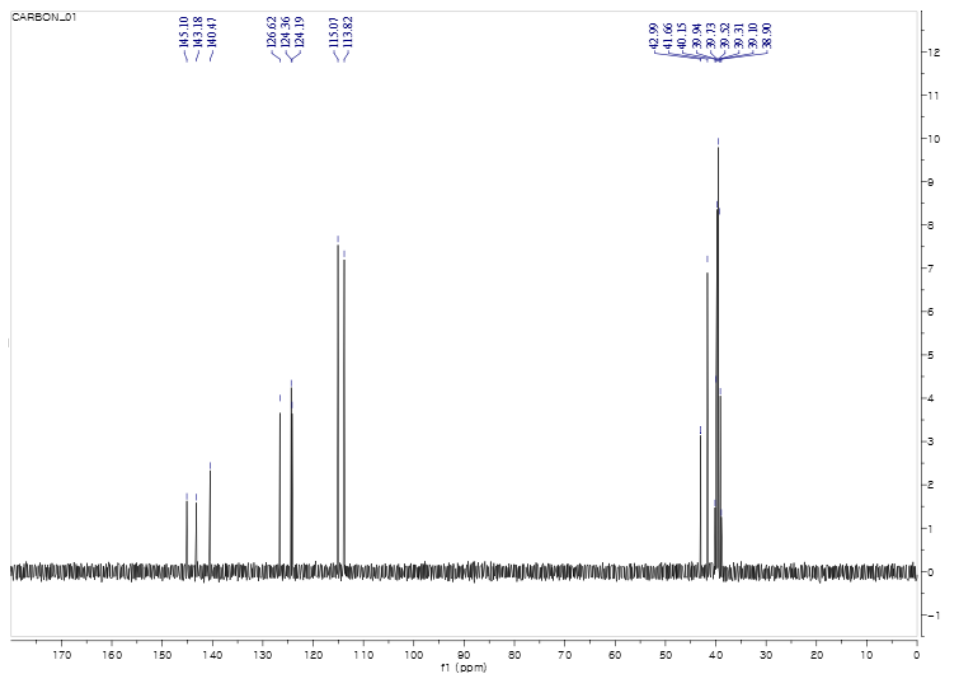

Figure S1. ${ }^{1} \mathrm{H}(\mathrm{a}, 400 \mathrm{MHz})$ and ${ }^{13} \mathrm{C}(\mathrm{b}, 100 \mathrm{MHz})$ NMR spectra of L1 in DMSO-d. 
(a)

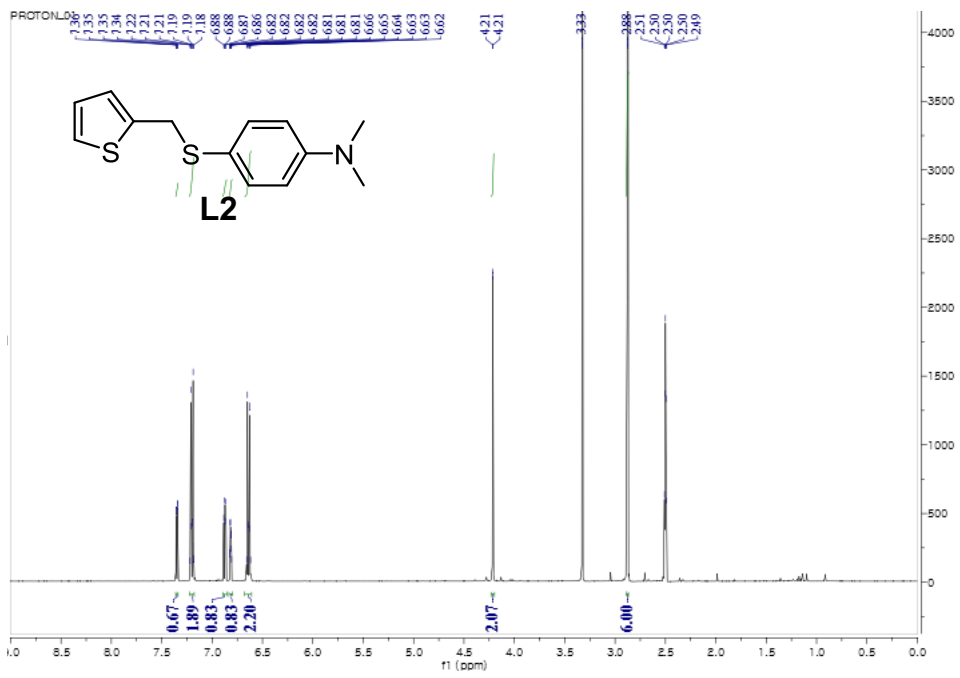

(b)

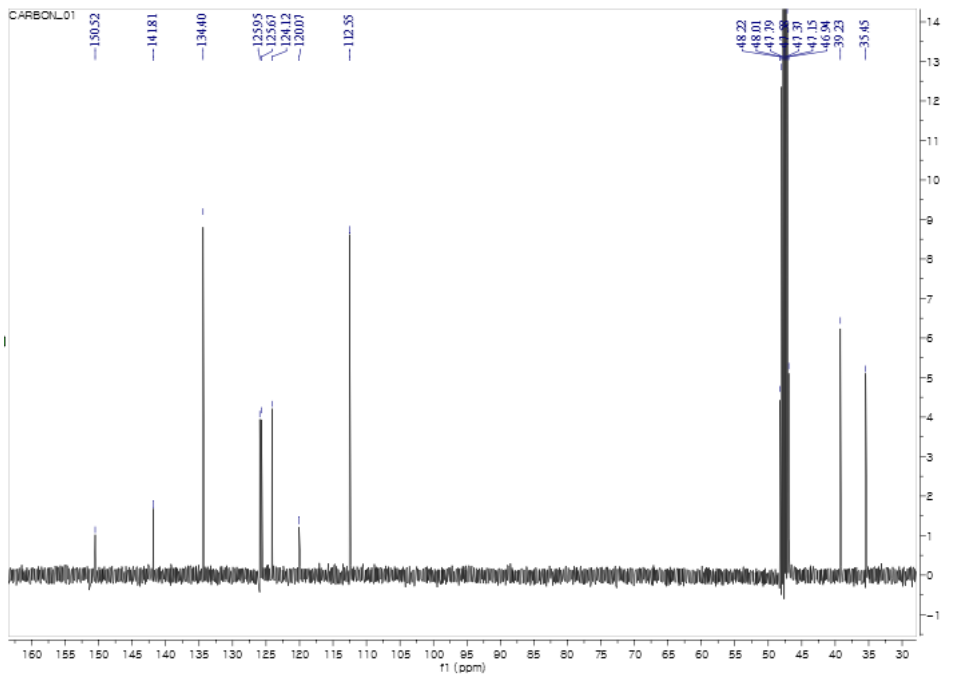

Figure S2. ${ }^{1} \mathrm{H}(\mathrm{a}, 400 \mathrm{MHz})$ and ${ }^{13} \mathrm{C}(\mathrm{b}, 100 \mathrm{MHz}) \mathrm{NMR}$ spectra of L2 in DMSO- $d_{6}$ and $\mathrm{CD}_{3} \mathrm{OD}$, respectively. 
(a)
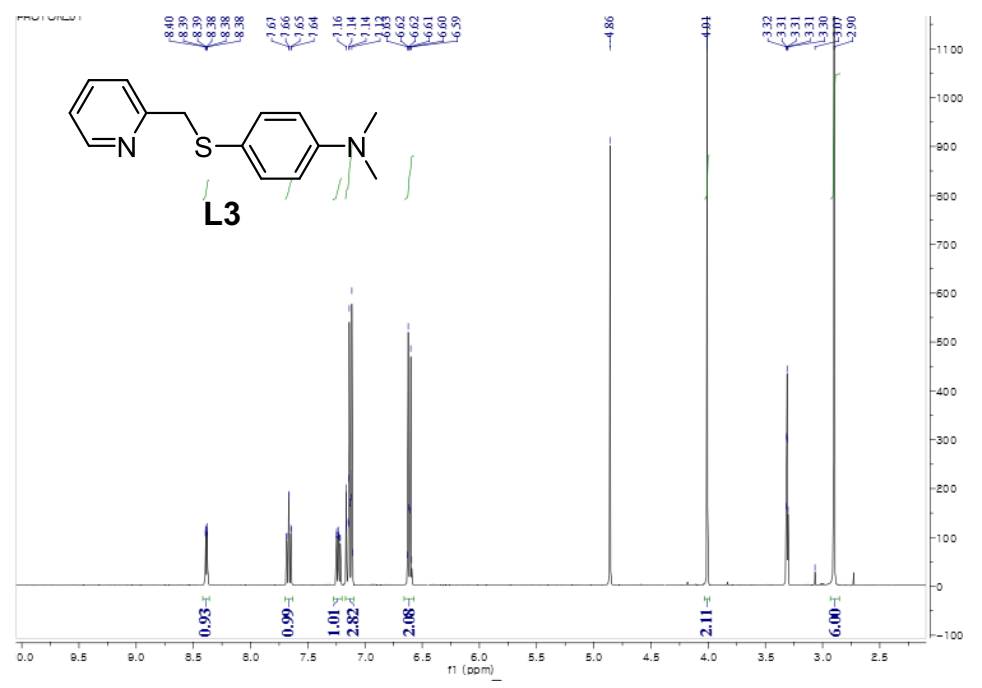

(b)

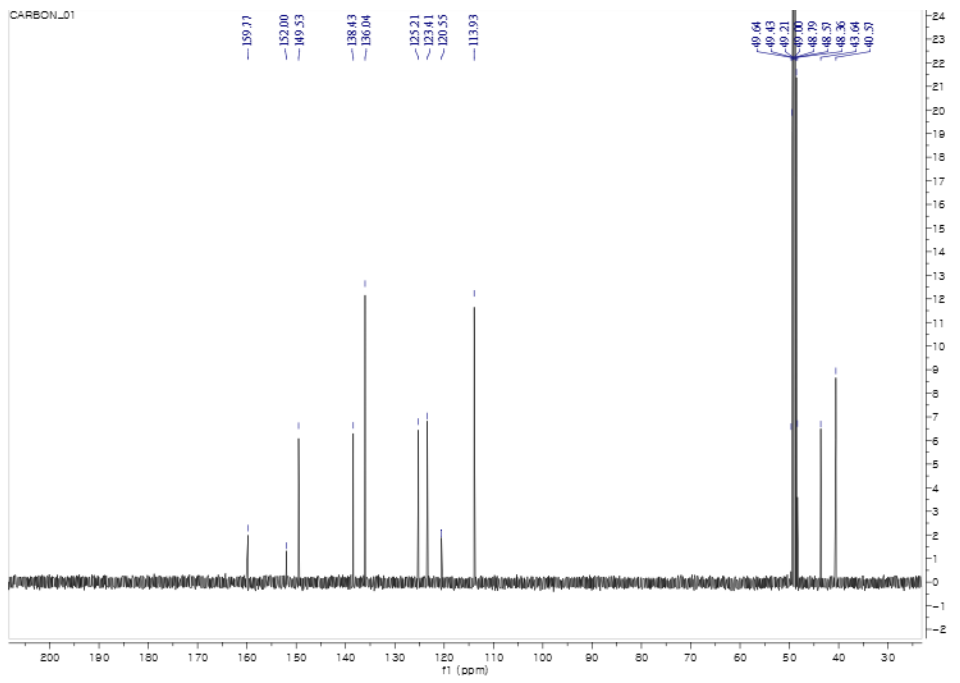

Figure S3. ${ }^{1} \mathrm{H}(\mathrm{a}, 400 \mathrm{MHz})$ and ${ }^{13} \mathrm{C}(\mathrm{b}, 100 \mathrm{MHz}) \mathrm{NMR}$ spectra of $\mathrm{L} 3$ in $\mathrm{CD}_{3} \mathrm{OD}$. 


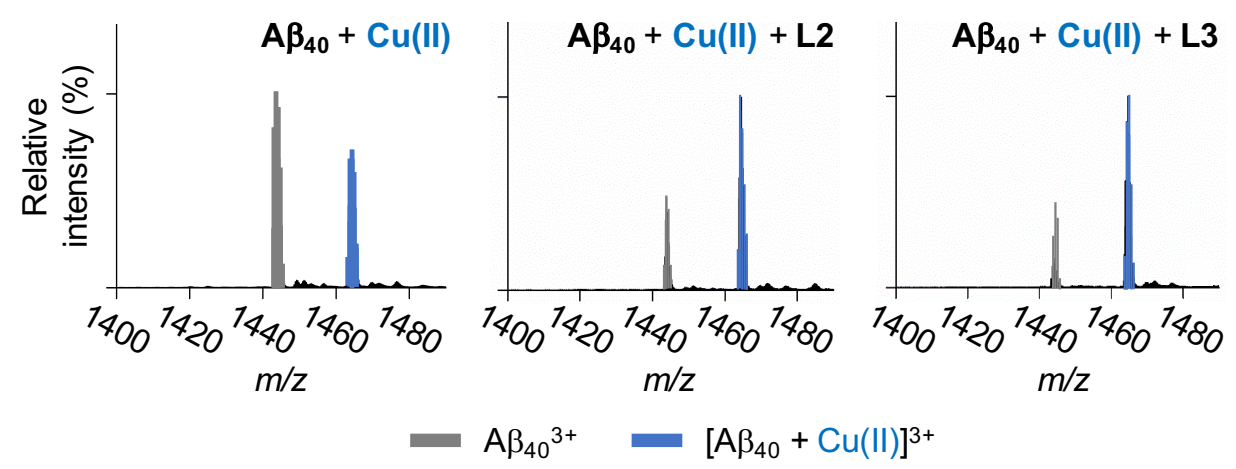

Figure S4. Interactions of L2 and L3 with $\mathrm{Cu}(\mathrm{II})$-treated $A \beta_{40}$, analyzed by ESI-MS. Metal-free and $\mathrm{Cu}(\mathrm{II})$-bound $\mathrm{A} \beta_{40}$ species are indicated in gray and blue, respectively. Conditions: $\left[\mathrm{A} \beta_{40}\right]=100 \mu \mathrm{M} ;\left[\mathrm{CuCl}_{2}\right]=100 \mu \mathrm{M}$; [compound] $=500 \mu \mathrm{M}$; incubation for $1 \mathrm{~h}$; $20 \mathrm{mM}$ ammonium acetate, $\mathrm{pH} 7.2 ; 37^{\circ} \mathrm{C}$; no agitation. The samples were diluted with $\mathrm{ddH}_{2} \mathrm{O}$ by 10 fold prior to injection to the mass spectrometer. 


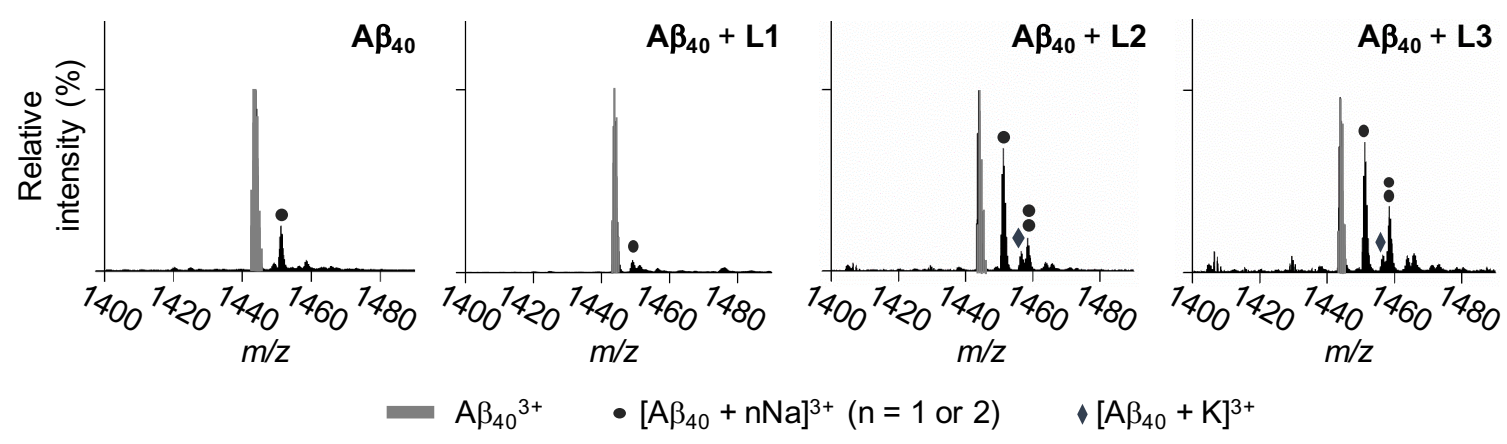

Figure S5. Interactions of L1-L3 with metal-free $A \beta_{40}$, analyzed by ESI-MS. $\mathrm{Na}^{+}$and $\mathrm{K}^{+}$ adducts of $A \beta_{40}$ were marked with black dots and diamonds, respectively. Conditions: $\left[\mathrm{A} \beta_{40}\right]=100 \mu \mathrm{M}$; [compound $]=500 \mu \mathrm{M}$; incubation for $3 \mathrm{~h} ; 20 \mathrm{mM}$ ammonium acetate, $\mathrm{pH} 7.2 ; 37^{\circ} \mathrm{C}$; no agitation. The samples were diluted with $\mathrm{dd}_{2} \mathrm{O}$ by 10 fold prior to injection to the mass spectrometer. 

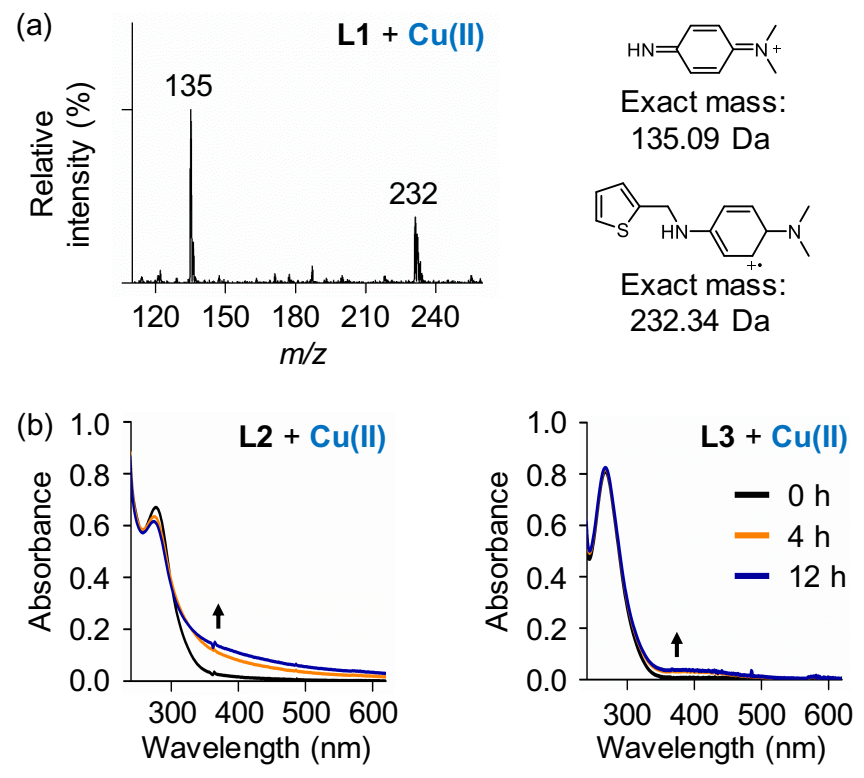

Figure S6. Transformations of L1-L3 in the presence of $\mathrm{Cu}(\mathrm{II})$. (a) $\mathrm{Cu}(\mathrm{II})$-mediated transformation of L1, monitored by ESI-MS. The fragmentation and oxidation of L1 were observed at 135 and $232 \mathrm{~m} / \mathrm{z}$, respectively. Conditions: [L1] $=50 \mu \mathrm{M} ;\left[\mathrm{CuCl}_{2}\right]=25 \mu \mathrm{M}$; $20 \mathrm{mM}$ ammonium acetate, $\mathrm{pH} 7.4 ; 37^{\circ} \mathrm{C}$; no agitation. The samples were diluted with $\mathrm{ddH}_{2} \mathrm{O}$ by 10 fold prior to injection to the mass spectrometer. (b) Optical spectra of $\mathbf{L 2}$ and L3 upon incubation with $\mathrm{Cu}(\mathrm{II})$ for 0,4 , and $12 \mathrm{~h}$. Conditions: [L2 or L3] $=50 \mu \mathrm{M}$; $\left[\mathrm{CuCl}_{2}\right]=25 \mu \mathrm{M} ; \mathrm{pH} 7.4$; room temperature; incubation for 1 (black), 4 (orange), and 12 h (blue). 

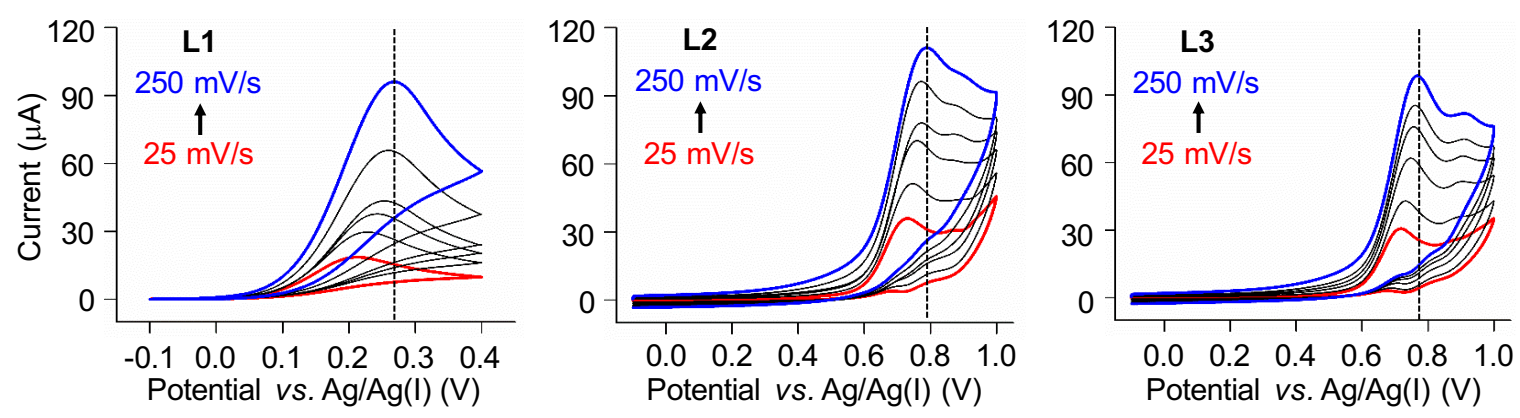

Figure S7. Oxidation potentials of L1-L3 at various scan rates in DMSO, measured by cyclic voltammetry. The dashed black lines indicate the oxidation potentials of compounds at $250 \mathrm{mV} / \mathrm{s}$. Conditions: [compound] $=1 \mathrm{mM} ; 0.1 \mathrm{M}$ tetra- $N$-butylammonium perchlorate (in DMSO); various scan rates [25 (red), 50, 100, 150, 200 and 250 (blue) mV/s]; room temperature; three electrodes composed of the glassy carbon working electrode, platinum counter electrode, and $\mathrm{Ag} / \mathrm{Ag}(\mathrm{I})$ reference electrode. 

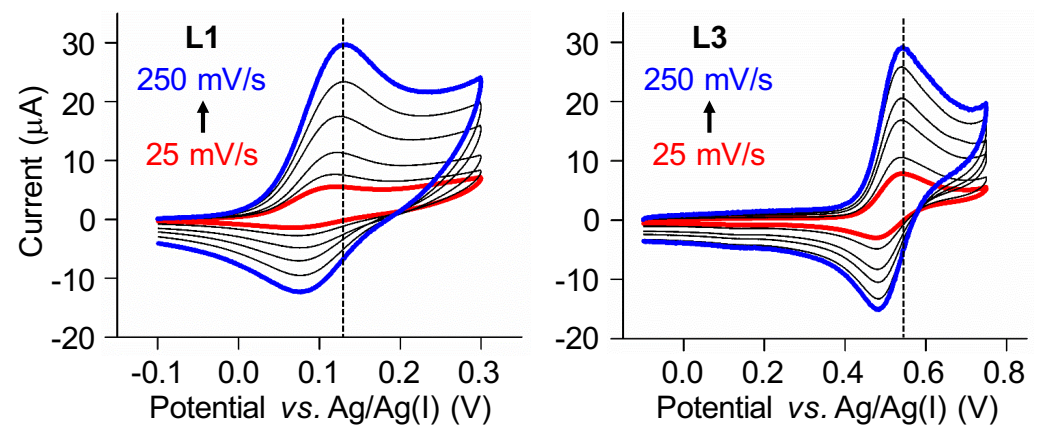

Figure S8. Oxidation potentials of $\mathbf{L} 1$ and $\mathbf{L} 3$ in $d_{d d H_{2}} \mathrm{O}$. The dashed black lines indicate the oxidation potentials of compounds at $250 \mathrm{mV} / \mathrm{s}$. Note that the $E_{p a}$ values of $\mathbf{L} 2$ could not be measured due to its limited solubility in $\mathrm{H}_{2} \mathrm{O}$. Conditions: [compound] = $1 \mathrm{mM} ; 1 \mathrm{M}$ $\mathrm{NaCl}$ (in $\mathrm{ddH}_{2} \mathrm{O}$ ); various scan rates [25 (red), 50, 100, 150, 200 and 250 (blue) mV/s]; room temperature; three electrodes composed of the glassy carbon working electrode, platinum counter electrode, and $\mathrm{Ag} / \mathrm{Ag}(\mathrm{I})$ reference electrode. 
(a)
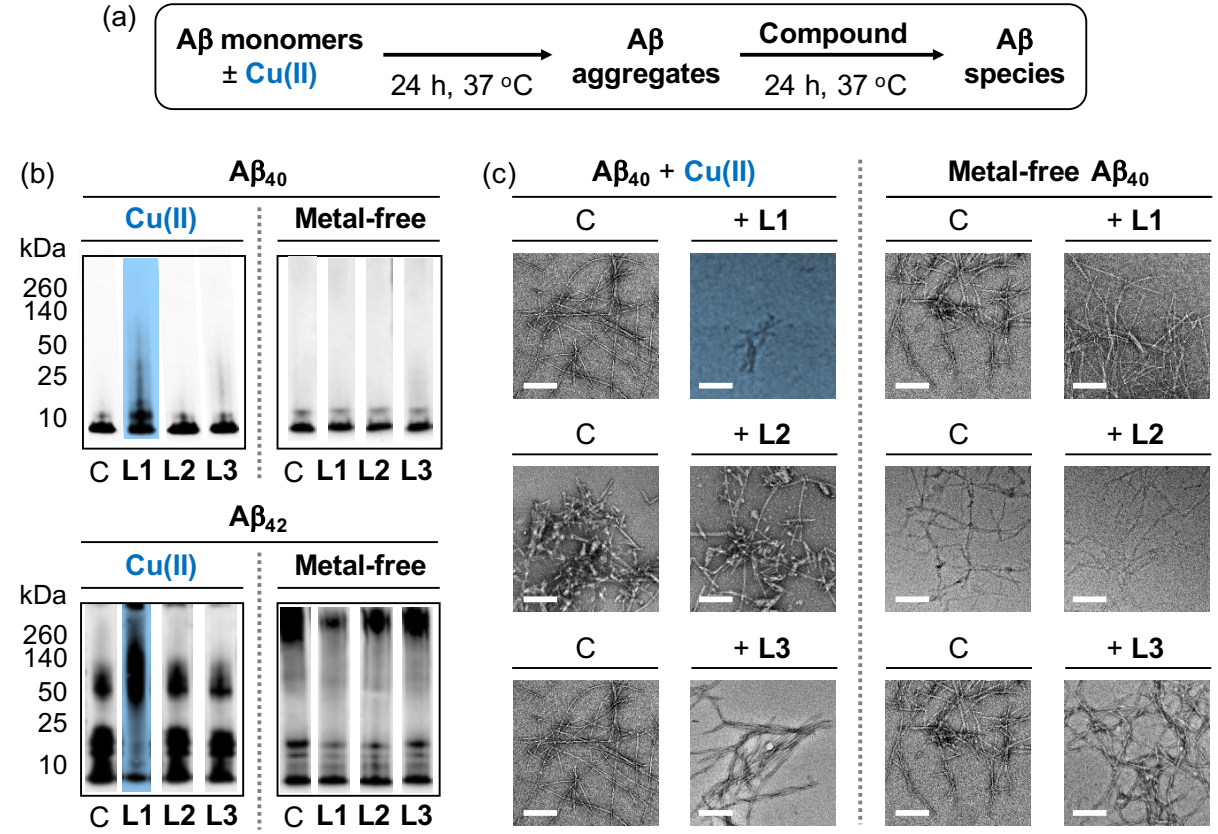

Figure S9. Impact of L1-L3 on preformed $\mathrm{Cu}(\mathrm{II})$-bound and metal-free $\mathrm{A} \beta$ aggregates. (a) Scheme of the disaggregation experiments. (b) Analysis of the size distribution of the resultant $A \beta_{40}$ (top) and $A \beta_{42}$ (bottom) species by gel/Western blot using an anti-A $\beta$ antibody (6E10). Lanes: (C) A $\beta \pm \mathrm{CuCl}_{2}$; (L1) C + L1; (L2) C + L2; (L3) C + L3. The original gel images are presented in Figure S10b. (c) Morphologies of the $\mathrm{Cu}(\mathrm{II})$-treated (left) and metal-free (right) $A \beta_{40}$ aggregates from (b), monitored by TEM. Scale bar $=200$ nm. Conditions: $[\mathrm{A} \beta]=25 \mu \mathrm{M}$; $\left[\mathrm{CuCl}_{2}\right]=25 \mu \mathrm{M}$; [compound] $=50 \mu \mathrm{M}$; pH 6.6 [for $\mathrm{Cu}(\mathrm{II})-$ containing samples] or $\mathrm{pH} 7.4$ (for metal-free samples); $37^{\circ} \mathrm{C}$; constant agitation. 
(a)

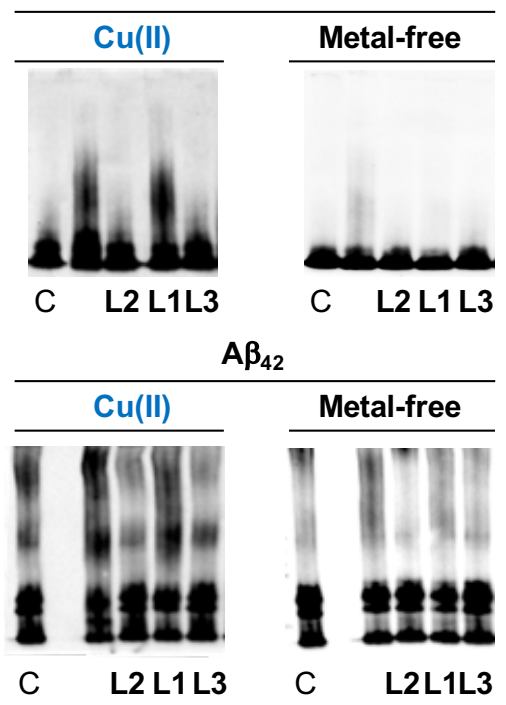

(b)

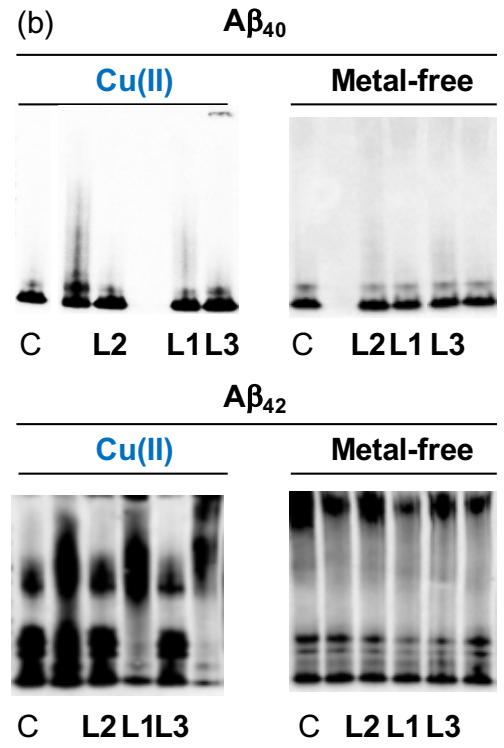

Figure S10. Original gel images from the (a) inhibition (Figure $5 b$ ) and (b) disaggregation (Figure S9b) experiments. 
(a)

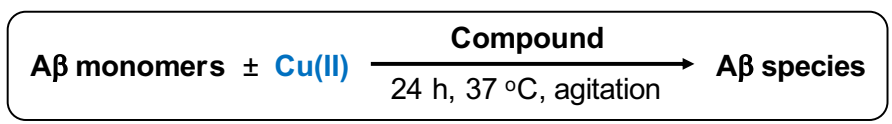

(b)

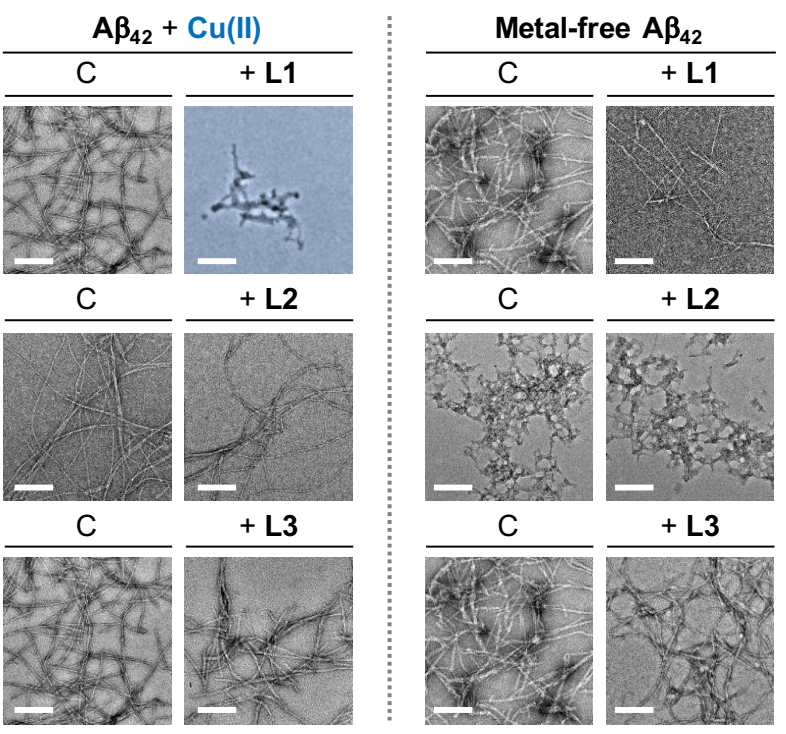

Figure S11. TEM images of the $A \beta_{42}$ aggregates generated upon incubation with L1-L3 from the inhibition experiments. (a) Scheme of the inhibition experiments. (b) Morphologies of the $\mathrm{Cu}(\mathrm{II})$-treated $A \beta_{42}$ (left) and metal-free $A \beta_{42}$ (right) aggregates, monitored by TEM. Scale bar $=200 \mathrm{~nm}$. Conditions: $[A \beta]=25 \mu \mathrm{M} ;\left[\mathrm{CuCl}_{2}\right]=25 \mu \mathrm{M}$; [compound] $=50 \mu \mathrm{M} ; \mathrm{pH} 6.6$ [for $\mathrm{Cu}(\mathrm{II})$-containing samples] or $\mathrm{pH} 7.4$ (for metal-free samples); $37^{\circ} \mathrm{C}$; constant agitation. 
(a)

\begin{tabular}{|c|c|c|c|c|}
\hline \multirow{2}{*}{$\begin{array}{c}A \boldsymbol{\beta} \text { monomers } \\
\pm \mathrm{Cu}(\mathrm{II})\end{array}$} & \multirow[b]{2}{*}{$24 \mathrm{~h}, 37^{\circ} \mathrm{C}$} & \multirow{2}{*}{$\begin{array}{c}\mathbf{A} \boldsymbol{\beta} \\
\text { aggregates }\end{array}$} & Compound & \multirow{2}{*}{$\begin{array}{c}A \beta \\
\text { species }\end{array}$} \\
\hline & & & $24 \mathrm{~h}, 37^{\circ} \mathrm{C}$ & \\
\hline
\end{tabular}

(b)

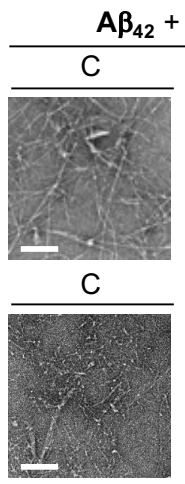

C

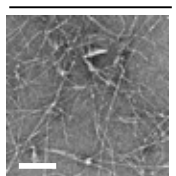

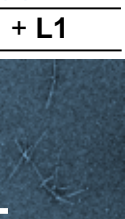

$+\mathrm{L} 2$

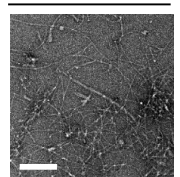

$+\mathrm{L3}$

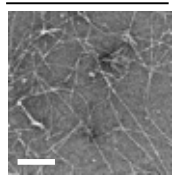

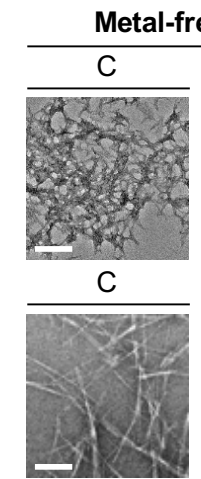

C

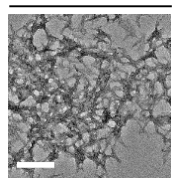

$+\mathrm{L} 3$

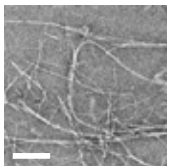

Figure S12. TEM images of the $A \beta_{42}$ aggregates formed upon incubation with L1-L3 from the disaggregation experiments. (a) Scheme of the disaggregation experiments. (b) Morphologies of the resultant $\mathrm{Cu}(\mathrm{II})$-treated $A \beta_{42}$ (left) and metal-free $A \beta_{42}$ (right) aggregates, monitored by TEM. Scale bar $=200 \mathrm{~nm}$. Conditions: $[\mathrm{A} \beta]=25 \mu \mathrm{M} ;\left[\mathrm{CuCl}_{2}\right]=$ $25 \mu \mathrm{M}$; [compound] = $50 \mu \mathrm{M}$; pH 6.6 [for $\mathrm{Cu}(\mathrm{II}$ )-containing samples] or $\mathrm{pH} 7.4$ (for metalfree samples); $37^{\circ} \mathrm{C}$; constant agitation. 


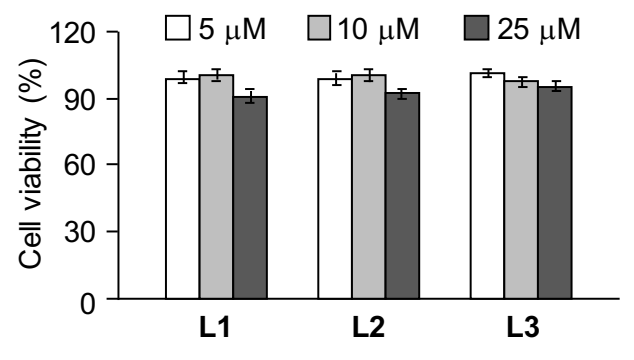

Figure S13. Toxicity of L1-L3 in SH-SY5Y cells. Cytotoxicity of compounds (5, 10, and $25 \mu \mathrm{M}$ ) was determined by the MTT assay. Cell viability was calculated in comparison to that obtained upon treatment with DMSO only $(1 \% \mathrm{v} / \mathrm{v})$. Error bars represent the standard deviation from three independent experiments $(P<0.1)$. 


\section{References}

(1) Lee, S.; Zheng, X.; Krishnamoorthy, J.; Savelieff, M. G.; Park, H. M.; Brender, J. R.; Kim, J. H.; Derrick, J. S.; Kochi, A.; Lee, H. J.; Kim, C.; Ramamoorthy, A.; Bowers, M. T.; Lim, M. H. Rational design of a structural framework with potential use to develop chemical reagents that target and modulate multiple facets of Alzheimer's disease. J. Am. Chem. Soc. 2015, 136, 299-310.

(2) Choi, J.-S.; Braymer, J. J.; Nanga, R. P.; Ramamoorthy, A.; Lim, M. H. Design of small molecules that target metal-A $\beta$ species and regulate metal-induced A $\beta$ aggregation and neurotoxicity. Proc. Natl. Acad. Sci. U. S. A. 2010, 107, 21990-21995.

(3) Derrick, J. S.; Kerr, R. A.; Nam, Y.; Oh, S. B.; Lee, H. J.; Earnest, K. G.; Suh, N.; Peck, K. L.; Ozbil, M.; Korshavn, K. J.; Ramamoorthy, A.; Prabhakar, R.; Merino, E. J.; Shearer, J.; Lee, J. Y.; Ruotolo, B. T.; Lim, M. H. A redox-active, compact molecule for cross-linking amyloidogenic peptides into nontoxic, off-pathway aggregates: in vitro and in vivo efficacy and molecular mechanisms. J. Am. Chem. Soc. 2015, 137, 14785-14797.

(4) Di, L.; Kerns, E. H.; Fan, K.; McConnell, O. J.; Carter, G. T. High throughput artificial membrane permeability assay for blood-brain barrier. Eur. J. Med. Chem. 2003, 38, 223-232.

(5) Avdeef, A.; Bendels, S.; Di, L.; Faller, B.; Kansy, M.; Sugano, K.; Yamauchi, Y. PAMPA-critical factors for better predictions of absorption. J. Pharm. Sci. 2007, 96, 2893-2909.

(6) Hindo, S. S.; Mancino, A. M.; Braymer, J. J.; Liu, Y.; Vivekanandan, S.; Ramamoorthy, A.; Lim, M. H. Small molecule modulators of copper-induced $A \beta$ aggregation. J. Am. Chem. Soc. 2009, 131, 16663-16665.

(7) Lee, H. J.; Korshavn, K. J.; Nam, Y.; Kang, J.; Paul, T. J.; Kerr, R. A.; Youn, I. S.; Ozbil, M.; Kim, K. S.; Ruotolo, B. T.; Prabhakar, R.; Ramamoorthy, A.; Lim, M. H. Structural and mechanistic insights into development of chemical tools to control individual and inter-related pathological features in Alzheimer's disease. Chem. Eur. J. 2017, 23, 2706-2715.

(8) Beck, M. W.; Oh, S. B.; Kerr, R. A.; Lee, H. J.; Kim, S. H.; Kim, S.; Jang, M.; 
Ruotolo, B. T.; Lee, J.-Y.; Lim, M. H. A rationally designed small molecule for identifying an in vivo link between metal-amyloid- $\beta$ complexes and the pathogenesis of Alzheimer's disease. Chem. Sci. 2015, 6, 1879-1886.

(9) Hyung, S. J.; DeToma, A. S.; Brender, J. R.; Lee, S.; Vivekanandan, S.; Kochi, A.; Choi, J.-S.; Ramamoorthy, A.; Ruotolo, B. T.; Lim, M. H. Insights into antiamyloidogenic properties of the green tea extract (-)-epigallocatechin-3gallate toward metal-associated amyloid- $\beta$ species. Proc. Natl. Acad. Sci. U. S. A. 2013, 110, 3743-3748.

(10) Mruk, D. D.; Cheng, C. Y. Enhanced chemiluminescence $(E C L)$ for routine immunoblotting: an inexpensive alternative to commercially available kits. Spermatogenesis 2011, 1, 121-122. 
